Research article

urn:1sid:zoobank.org:pub:FA094A78-E59F-405E-B95A-3CF7F92F9E8A

\title{
On Brazilian Austrotinodes Schmid, 1955 (Insecta, Trichoptera, Ecnomidae): new species, new distributional records and an updated checklist
}

\author{
Leandro Lourenço DUMAS ${ }^{1, *}$, Wagner Rafael M. de SOUZA ${ }^{1,2} \&$ \\ Isabela Cristina $\mathrm{ROCHA}^{1,3}$ \\ ${ }^{1}$ Departamento de Zoologia, Instituto de Biologia, Universidade Federal do Rio de Janeiro, \\ Caixa Postal 68044, Cidade Universitária, 21941-971, Rio de Janeiro, RJ, Brazil. \\ ${ }^{2,3}$ Programa de Pós-graduação em Zoologia, Museu Nacional, \\ Universidade Federal do Rio de Janeiro, Brazil. \\ *Corresponding author: 1ldumas82@gmail.com \\ ${ }^{2}$ Email: faelwagner@gmail.com \\ ${ }^{3}$ Email: isaabio@hotmail.com \\ ${ }^{1}$ urn:1sid:zoobank.org:author:55D870A2-6CE2-492E-8E05-2077D5C0CB11 \\ ${ }^{2}$ urn:1sid:zoobank.org:author:5B0992DC-B160-4C45-B56F-65500832B9C5 \\ ${ }^{3}$ urn:1sid:zoobank.org:author:FB822EC5-2E9B-4326-B1D9-714BF1C8F037
}

\begin{abstract}
The genus Austrotinodes contains 55 species, largely distributed in the Neotropics, with a few species occurring in the Australian Region. In Brazil, 10 species have been recorded, mainly in the southern and southeastern regions. Herein, we describe 13 new species from Brazil, all of them named in memory of great Brazilian scientists: Austrotinodes absaberi sp. nov., A. adolfolutzi sp. nov., A. berthalutzae sp. nov., A. chagasi sp. nov., A. costalimai sp. nov., A. cruzi sp. nov., A. donagrazielae sp. nov., A. gusmaoi sp. nov., A. lattesi sp. nov., A. lenti sp. nov., A. santosdumonti sp. nov., A. vanzolinii sp. nov. and A. vitalbrazili sp. nov. Additionally, we give new distribution records for A. amazonensis Flint \& Denning, 1989, A. longispinum Thomson \& Holzenthal, 2010, A. paraguayensis Flint, 1983 and $A$. taquaralis Thomson \& Holzenthal, 2010. We also provide new diagnoses and illustrations for A. amazonensis and A. paraguayensis, to facilitate identification of those species.
\end{abstract}

Keywords. Brazil, caddisflies, ecnomids, Neotropical, taxonomy.

Dumas L.L., Souza W.R.M. de \& Rocha I.C. 2017. On Brazilian Austrotinodes Schmid, 1955 (Insecta, Trichoptera, Ecnomidae): new species, new distributional records and an updated checklist. European Journal of Taxonomy 297: 1-40. https://doi.org/10.5852/ejt.2017.297

\section{Introduction}

The caddisfly family Ecnomidae was originally described as a subfamily of Hydropsychidae (Ulmer 1903). Later it was transferred to Polycentropodidae (Ulmer 1907) and then to Psychomyiidae (Ulmer 1910). Ultimately, Lepneva (1970) gave ecnomids a family status, based primarily on larval 
characteristics. Currently, 11 extant genera are recognized in the family: Ecnomus McLachlan, 1864, with more than 260 species widespread in the Paleartic, Oriental and Afrotropical regions, Parecnomina Kimmins, 1957, with seven species endemic to Africa, Austrotinodes Schmid, 1955, with approximately 50 species distributed throughout the Neotropical and Australian regions, the monotypic Neotropical genus Chilocentropus Navás, 1934, presently considered a nomen dubium by Holzenthal et al. (2007) and Absensomina Cartwright, 2010 (1 species), Daternomina Neboiss, 2003 (16 species), Ecnomina Kimmins in Mosely \& Kimmins, 1953 (36 species), Neboissomina Cartwright, 2011 (7 species), Wellsomina Cartwright, 2010 (12 species), Agmina Ward \& Schefter, 2000 (27 species), and Caledomina Johanson, 2011 (1 species), all from the Australian region, with the last two endemic to New Caledonia.

Austrotinodes was established by Schmid (1955) to include A. latior Schmid, 1955 and A. angustior Schmid, 1955, both from Chile, the former subsequently synonymized with A. talcanus (Navás, 1934), originally described in the genus Tinodes Curtis, 1834. After two revisional works (Flint 1973; Flint \& Denning 1989) and several additional species descriptions (e.g., Angrisano 1994; Flint 1983, 1996; Bowles 1995; Muñoz-Quezada \& Holzenthal 1993; Thomson \& Holzenthal 2010), 44 species have now been reported from the New World. Austrotinodes is largely distributed in the Neotropics, with a few species extending into the extreme southwestern USA (Bowles 1995). Recently, Cartwright (2009) recorded the genus for the first time in Australia and described 11 new species from that country. In Brazil, the genus is represented by 10 species (Table 1), mostly distributed in the Atlantic Rainforest. Only Austrotinodes amazonensis Flint \& Denning, 1989 and A. ariasi Flint \& Denning, 1989 are registered from the Amazon Basin. Based on the new species recently described (Thomson \& Holzenthal 2010) and on the number of new species described here, the diversity of Brazilian Austrotinodes seems to be greatly underestimated.

According to Flint $(1973,1983)$ the genus consists of two distinct groups: 1) a Chilean/Argentinian group, in which the hind wing has a closed discoidal cell and three anal veins, the forewing has cross veins $r-m$ and $m$ contiguous at fork 3 , and females have two lobes on sternite VIII; 2) a group containing the remaining new world species, in which the hind wing has an open discoidal cell and only two anal veins, the forewing with cross veins $r-m$ and $m$ not contiguous at fork 3 and most females possess a single lobe on sternite VIII. The genus Austrotinodes was considered monophyletic according to a phylogenetic analysis of higher-level relationships within Ecnomidae based on molecular data (Johanson \& Espeland 2010). However, the analysis only included species of Chilean/Argentinian group.

In this paper we describe and illustrate 13 new species of Austrotinodes from Brazil. Additionally, new distributional records are given for A. amazonensis, A. longispinum Thomson \& Holzenthal, 2010, A. paraguayensis Flint, 1983 and A. taquaralis Thomson \& Holzenthal, 2010. We also provide new illustrations and diagnoses of the male genitalia of $A$. amazonensis and A. paraguayensis, to facilitate comparison with others species. Finally, the paper presents an updated checklist of the Austrotinodes species reported from Brazil (Table 1).

\section{Material and methods}

Specimens were collected using Malaise traps (Gressit \& Gressit 1962) or Pennsylvania light traps (Frost 1957) and preserved in 96\% ethanol. For examination of the male genital structures, the abdomen was removed and cleared in a heated solution of $10 \% \mathrm{KOH}$, followed by a rinse in distilled water, and mounted temporarily in glycerin or glycerin jelly on a slide for viewing and drawing. After that, removed abdomens were stored permanently in micro vials with $96 \%$ ethanol. Pencil sketches were made using a Carl Zeiss compound light microscope (model Axiolab) equipped with camera lucida and then scanned and used as templates to trace graphic vectors in Adobe Illustrator (v. 6 Adobe Systems, Inc.). Morphological terminology used for male genitalia follows that of Flint \& Denning (1989) and Thomson \& Holzenthal (2010). 
Table 1. Brazilian Austrotinodes. Codes for Brazilian states are as follows: Amazonas (AM), Ceará (CE), Espírito Santo (ES), Mato Grosso do Sul (MS), Minas Gerais (MG), Pará (PA), Paraná (PR), Piauí (PI), Rio de Janeiro (RJ), Santa Catarina (SC), and São Paulo (SP). Codes in bold represent new state records.

\begin{tabular}{lcc}
\hline Species & Distribution & Brazilian States \\
\hline Austrotinodes absaberi sp. nov. & Brazil & MG \\
Austrotinodes abrachium Thomson \& Holzenthal, 2010 & Brazil & MG \\
Austrotinodes adolfolutzi sp. nov. & Brazil & MG \\
Austrotinodes amazonensis Flint \& Denning, 1989 & Brazil & AM, MG \\
Austrotinodes ariase Flint \& Denning, 1989 & Brazil & AM, PA \\
Austrotinodes belchiores Thomson \& Holzenthal, 2010 & Brazil & MG \\
Austrotinodes berthalutzae sp. nov. & Brazil & MS \\
Austrotinodes bracteatus Flint \& Denning, 1989 & Brazil & SP \\
Austrotinodes chagasi sp. nov. & Brazil & ES, PR, RJ, SC, SP \\
Austrotinodes costalimai sp. nov. & Brazil & SP \\
Austrotinodes cruzi sp. nov. & Brazil & ES \\
Austrotinodes donagrazielae sp. nov. & Brazil & SP \\
Austrotinodes gusmaoi sp. nov. & Brazil & SP \\
Austrotinodes lattesi sp. nov. & Brazil & SC, SP \\
Austrotinodes lenti sp. nov. & Brazil & MG \\
Austrotinodes longispinum Thomson \& Holzenthal, 2010 & Brazil & ES, RJ, SP \\
Austrotinodes paraguayensis Flint, 1983 & Brazil, Paraguay & CE, MG, PA, PI \\
Austrotinodes prolixus Flint \& Denning, 1989 & Brazil & MG, SP \\
Austrotinodes santosdumonti sp. nov. & Brazil & PR, RJ, SP \\
Austrotinodes taquaralis Thomson \& Holzenthal, 2010 & Brazil & ES, MG, RJ \\
Austrotinodes uruguayensis Angrisano, 1994 & Brazil & PR \\
Austrotinodes vanzolinii sp. nov. & Brazil & SP \\
Austrotinodes vitalbrazili sp. nov. & Brazil & MG \\
\hline
\end{tabular}

Specimens studied are deposited at the Coleção Entomológica Professor José Alfredo Pinheiro Dutra, Departamento de Zoologia, Universidade Federal do Rio de Janeiro, Rio de Janeiro (DZRJ). Codes for Brazillian states are as follow: Amazonas (AM), Ceará (CE), Espírito Santo (ES), Mato Grosso do Sul (MS), Minas Gerais (MG), Pará (PA), Paraná (PR), Ceará (CE), Rio de Janeiro (RJ), Santa Catarina (SC), and São Paulo (SP).

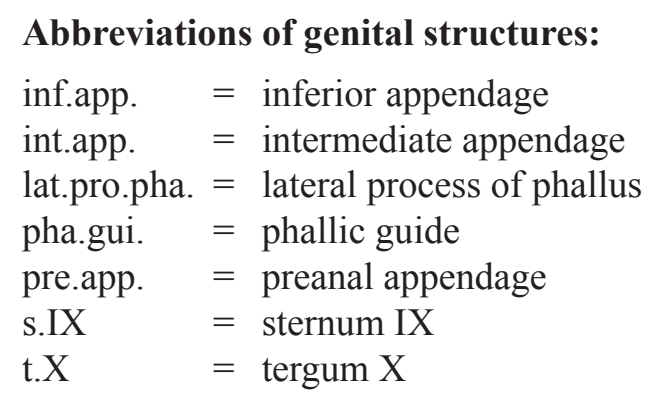




\title{
Results
}

\author{
Class Hexapoda Blainville, 1816 \\ Order Trichoptera Kirby, 1813 \\ Suborder Annulipalpia Martynov, 1924 \\ Superfamily Psychomyioidea Ivanov, 2002 \\ Family Ecnomidae Ulmer, 1903 \\ Genus Austrotinodes Schmid, 1955 \\ Austrotinodes absaberi sp. nov. \\ urn:Isid:zoobank.org:act:231301EA-9ECA-4C46-AFAB-3FE6ED93DFC8
}

Figs 1, 14

\section{Diagnosis}

Austrotinodes absaberi sp. nov. is most similar to $A$. gusmaoi sp. nov., A. donagrazielae sp. nov. and A. taquaralis, resembling these species in the elongate, upwards curved intermediate appendages with 3 apical spine-like setae. It differs in that the apical portion of the phallus has a long, slender posterolateral spine, absent in the other species. Furthermore, the intermediate appendage in $A$. absaberi sp. nov. and A. gusmaoi sp. nov. lacks a basoventral seta. Other differences distinguishing $A$. absaberi sp. nov. from related species are the shape of the phallic guide, which is smaller and strongly arched in the species described here, and the more elongate preanal appendages when compared with those of $A$. gusmaoi sp. nov. The differences among these species are relatively minor, and they are here placed informally in the taquaralis Group based on: (1) the elongate, upwards curved intermediate appendages with 3 apical spines; (2) phallus with lateral process elongate, bifid, bearing an elongate and more robust dorsal branch and a short and slender ventral branch.

\section{Etymology}

The species is dedicated to the Brazilian biogeographer, geologist and environmentalist Aziz Nacib Ab'Saber, who was born at São Luiz do Paraitinga in São Paulo state in 1924 and died in 2012. Aziz Ab'Saber was the first person to classify scientifically the Brazilian and South-America territory in morphoclimatic domains. He also contributed to the "Pleistocene Refuge Hypothesis", an attempt to explain the distribution and diversification of Neotropical taxa as a result of their isolation in forest fragments during glacial periods.

\section{Material examined}

\section{Holotype}

BRAZIL: ${ }^{\lambda}$, Minas Gerais, Itabirito, Vale dos Tropeiros, Cachoeira dos Cruzados, 20²1 $16.6^{\prime \prime}$ S, 43³8'10.5” W, 1037 m, 9 Oct. 2010, L.L. Dumas leg. (DZRJ).

\section{Paratypes}

BRAZIL: $2 \hat{\jmath} \widehat{\partial}$, same data as holotype (DZRJ); $1 \hat{\jmath}$, same locality, 10 Oct. 2010, L.L. Dumas leg. (DZRJ).

\section{Description}

ADULT. Length of forewing 4.75-5.15 mm $(\mathrm{n}=4)$. In alcohol, general color golden brown, with yellowish brown sclerites; antennae stramineous, dorsum of head golden brown, with pale yellow and dark brown setae; thorax golden brown dorsally, light yellow ventrally; legs yellow, legs segments with brown setae; wings pale brown, forewing with fine pale brown setae dorsally. 

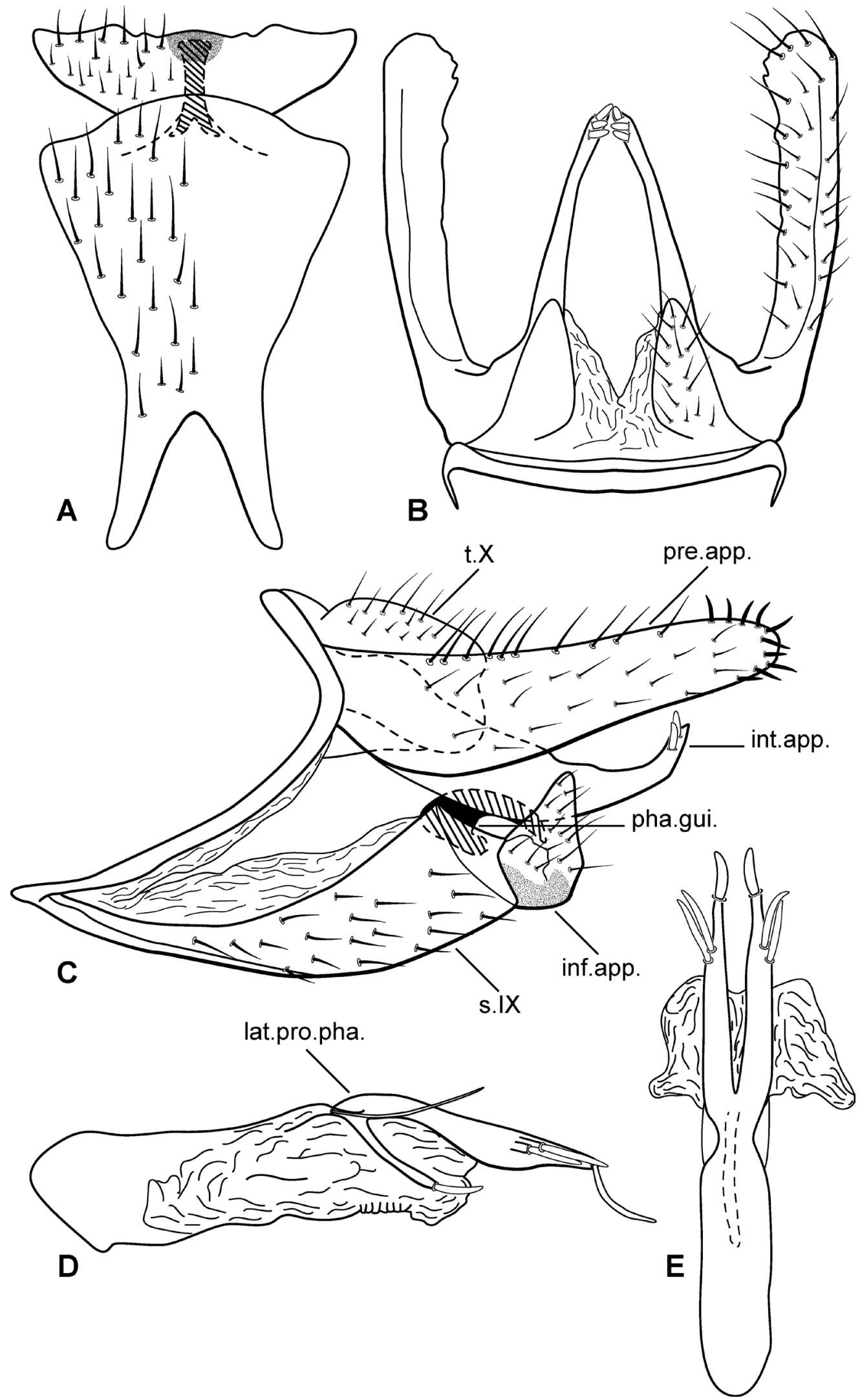

Fig. 1. Austrotinodes absaberi sp. nov., male genitalia. A. Ventral view. B. Dorsal view. C. Left lateral view. D. Phallic apparatus, left lateral view. E. Phallic apparatus, dorsal view. 
WINGS. Forewing with R1 forked apically, forks II-V present; hind wing with forks II, III and V, discoidal cell absent.

Male genitalia. Segment IX deeply divided, sternum elongate; in lateral view, narrow basally, enlarging apically, ventral margin slightly convex; in ventral view, about 2 times as long as wide, enlarging apically, apical margin strongly convex. Phallic guide darkly sclerotized, elevated over inferior appendages; in lateral view, strongly arched, base broad, apex subacute, reaching middle of inferior appendage. Inferior appendages fused mesally, attached apicomesally on sternum IX; in lateral view, short, subtriangular, apex rounded; in ventral view, lateral lobes elongate, directed laterad, posterior margin almost straight, gently crenulated. Tergum X divided into pair of semimembranous oval lobes, bearing slender dorsal setae; in lateral view, trapezoidal. Preanal appendages long, surface setose, margin slightly crenulated, almost parallel-sided, apex rounded. Intermediate appendages long, approximately $3 / 4$ length of preanal appendage; in lateral view, wide at base, tapering apically, curved dorsad, with 3 spines at apex (some paratypes with a spine-like seta at mid-length, absent in holotype). Phallus with sclerotized phallobase and membranous apicoventral region, with 1 very elongate, posterolateral spine-like seta; lateral process elongate, bifid; dorsal branch long, wide, with row of 2 subapical and 1 apical spines, the apical one longer and curved; ventral branch short, narrow, with 1 apical spine; without basomesal process.

\title{
Distribution
}

Brazil (MG).

\author{
Austrotinodes adolfolutzi sp. nov. \\ urn:1sid:zoobank.org:act:0548DA06-2DEF-4233-BEF6-B93DD5F55606
} Figs 2, 14

\section{Diagnosis}

This new species can be distinguished from all other species of the genus by the shape of intermediate appendages, which are slightly curved dorsad near apex, bearing several spine-like setae: 1 long, projecting mesoventral, followed by a row of 4 or 5 lateroventral stout, spine-like setae, and an isolated apical one. The elongate and spinous, oval phallus resembles those of $A$. bracteatus Flint \& Denning, 1989, A. lattesi sp. nov. and A. costalimai sp. nov.

\section{Etymology}

The species is dedicated to the Brazilian medical zoologist and epidemologist Adolfo Lutz, who was born at Rio de Janeiro in Rio de Janeiro state in 1855 and died in 1940. Adolfo Lutz was the first Latin American scientist to study in depth and to confirm the mechanisms of transmission of yellow fever by Aedes aegypti (Linnaeus, 1762) mosquitoes. His dedication to public health was also paramount in the research and fight to control various epidemics in many points in Brazil. Because of this he is recognized as the father of tropical medicine and medical zoology in Brazil.

\section{Material examined}

\section{Holotype}

BRAZIL: $\widehat{\partial}$, Minas Gerais, São Roque de Minas, PN da Serra da Canastra, Fazenda Velha, Córrego dos Pombos, 20¹4'56.6" S, 46³8'04.9" W, 997 m, 2 Apr. 2014, J.L. Nessimian, A.L.H. Oliveira, L.L. Dumas and S.P. Gomes leg. (DZRJ).

\section{Paratypes}

BRAZIL: 1 đ, 1 +, Minas Gerais, São Roque de Minas, PN da Serra da Canastra, parte baixa da Cachoeira Casca D'anta, Rio São Francisco, 20¹8'22.27" S, 46³1'23.40" W, 882 m, 1 Oct. 2015, 

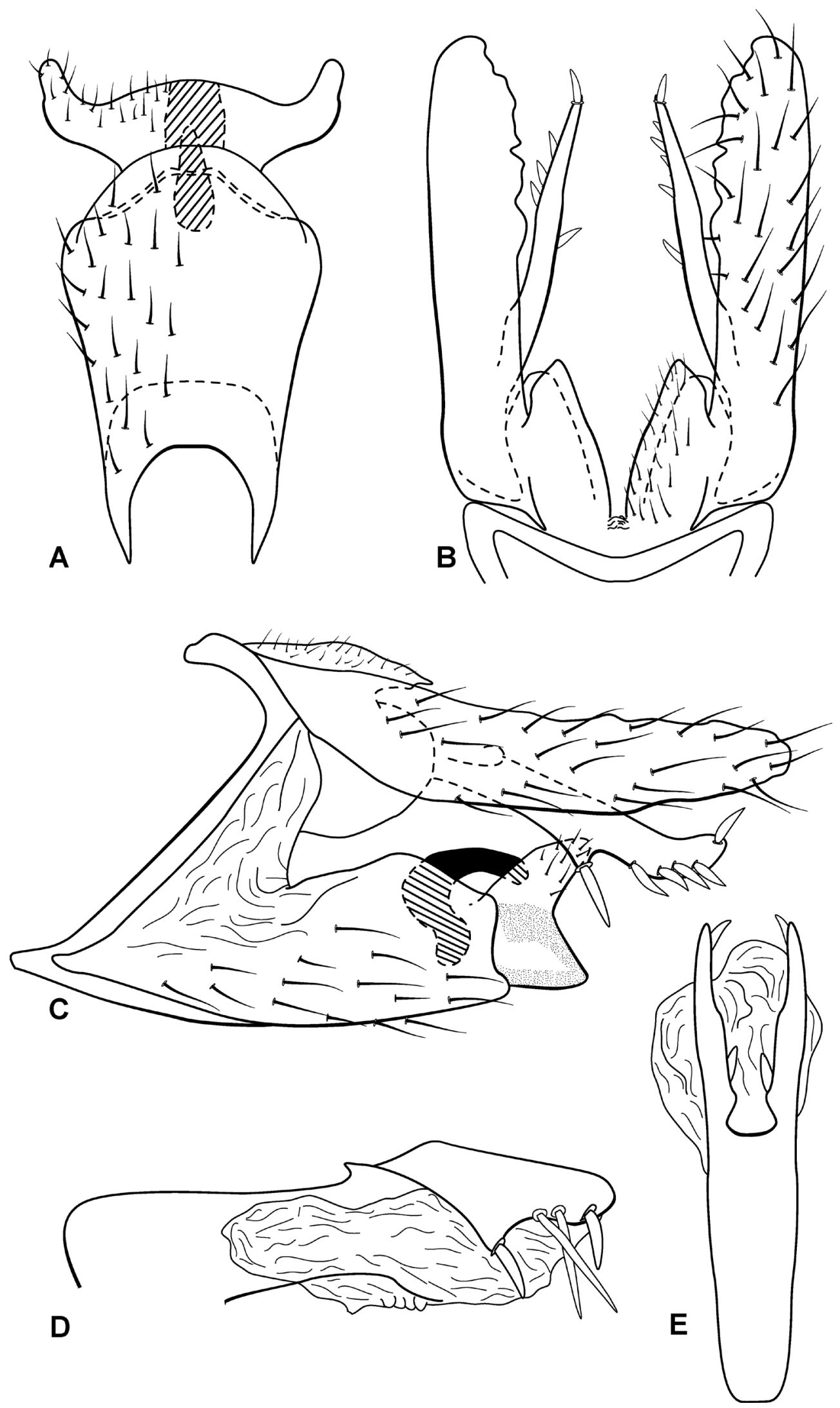

Fig. 2. Austrotinodes adolfolutzi sp. nov., male genitalia. A. Ventral view. B. Dorsal view. C. Left lateral view. D. Phallic apparatus, left lateral view. E. Phallic apparatus, dorsal view. 
J.L. Nessimian, L.L. Dumas, I.C. Rocha, P.M. Souto and N. Ferreira jr leg. (DZRJ); 5 $\widehat{\partial}, 1$ q, São Roque de Minas, PN da Serra da Canastra, parte baixa da Cachoeira Casca D'anta, Rio São Francisco, $20^{\circ} 18^{\prime} 32.60^{\prime \prime} \mathrm{S}, 46^{\circ} 31^{\prime} 22.20^{\prime \prime} \mathrm{W}, 895$ m, 1 Oct. 2015, J.L. Nessimian, L.L. Dumas, I.C. Rocha, P.M. Souto and N. Ferreira jr leg. (DZRJ); 1 ô, São Roque de Minas, PN da Serra da Canastra, pousada Dois Irmãos, Córrego do Luciano, 20¹8'42" S, 46³2'08.90" W, 860 m, 1 Oct. 2015, J.L. Nessimian, L.L. Dumas, I.C. Rocha, P.M. Souto and N. Ferreira jr leg. (DZRJ).

\title{
Description
}

AduLt. Length of forewing $3.75-5.80 \mathrm{~mm}(\mathrm{n}=10)$. In alcohol, general color golden brown, with golden brown sclerites; antennae light yellow, dorsum of head dark golden brown, with pale yellow and dark brown setae; thorax golden brown dorsally, light yellow ventrally; legs yellow, legs segments with brown setae; wings pale brown, forewing with fine pale brown setae dorsally.

WINGS. Forewing with R1 forked apically, forks II-V present; hind wing with forks II, III and V, discoidal cell absent.

Male Genitalia. Segment IX deeply divided, sternum elongated; in lateral view, apparently enlarging subapically, ventral margin slightly convex; in ventral view, about 2 times as long as wide, enlarged subapically, apical margin broadly convex. Phallic guide darkly sclerotized, not highly elevated; in lateral view, arched, base moderately broad, apex rounded, reaching middle of inferior appendage. Inferior appendages fused mesally, attached apicomesally on sternum IX; in lateral view, stout, larger at base, apex subacute; in ventral view, lateral lobes elongate, directed posterad, posterior margin convex, not crenulated. Tergum X divided into pair of semimembranous ovate lobes, lobes bulbous, bearing slender dorsal setae along inner margin; in lateral view, elongate, tip pointed. Preanal appendages long, surface setose, margin crenulated, parallel-sided, apex rounded. Intermediate appendages long, almost same length as preanal appendage; in lateral view, parallel-sided, slightly curved dorsad near apex, with 1 projected mesoventral spine-like setae, row of 4-5 lateroventral and 1 apical spine-like setae. Phallus with sclerotized phallobase and membranous apicoventral region; lateral process moderately elongate, oval, widest at midlength, with 1 stout mesolateral spine, dorsal branch long, wide, with row of 3 stout ventral spines near apex, the 2 subapical ones 2 times longer than the more apical one; without basomesal process.

\section{Distribution}

Brazil (MG).

\author{
Austrotinodes berthalutzae sp. nov. \\ urn:1sid:zoobank.org:act:23E5DA21-324D-43BF-9145-FA348966AE86
}

Figs 3, 14

\section{Diagnosis}

The new species resembles A. adamsae Flint, 1996 and A. contubernalis Flint \& Denning, 1989 in having an elongate lateral process of the phallus with a single spine on the dorsal branch and two on the ventral branch, the first median and the second apical. The phallic guide, in lateral view, is also similar in all three species, but shorter in A. contubernalis. The intermediate appendages can easily distinguish this species from $A$. adamsae and A. contubernalis, both of which have four spines on the appendage, whereas $A$. berthalutzae sp. nov. bears only three. Additionally, in $A$. berthalutzae sp. nov. all spines are apically positioned, while in A. adamsae and A. contubernalis one stout spine is positioned at apical third and midlength, respectively. The new species is also similar to A. amazonensis in the shape of segment IX and in having a straight phallic guide; additionally, the inferior appendages of both these 


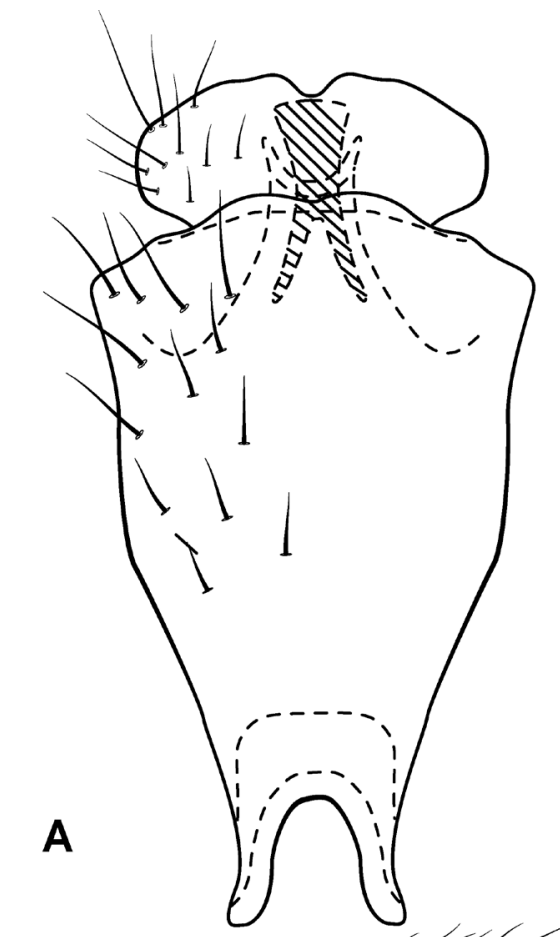

B
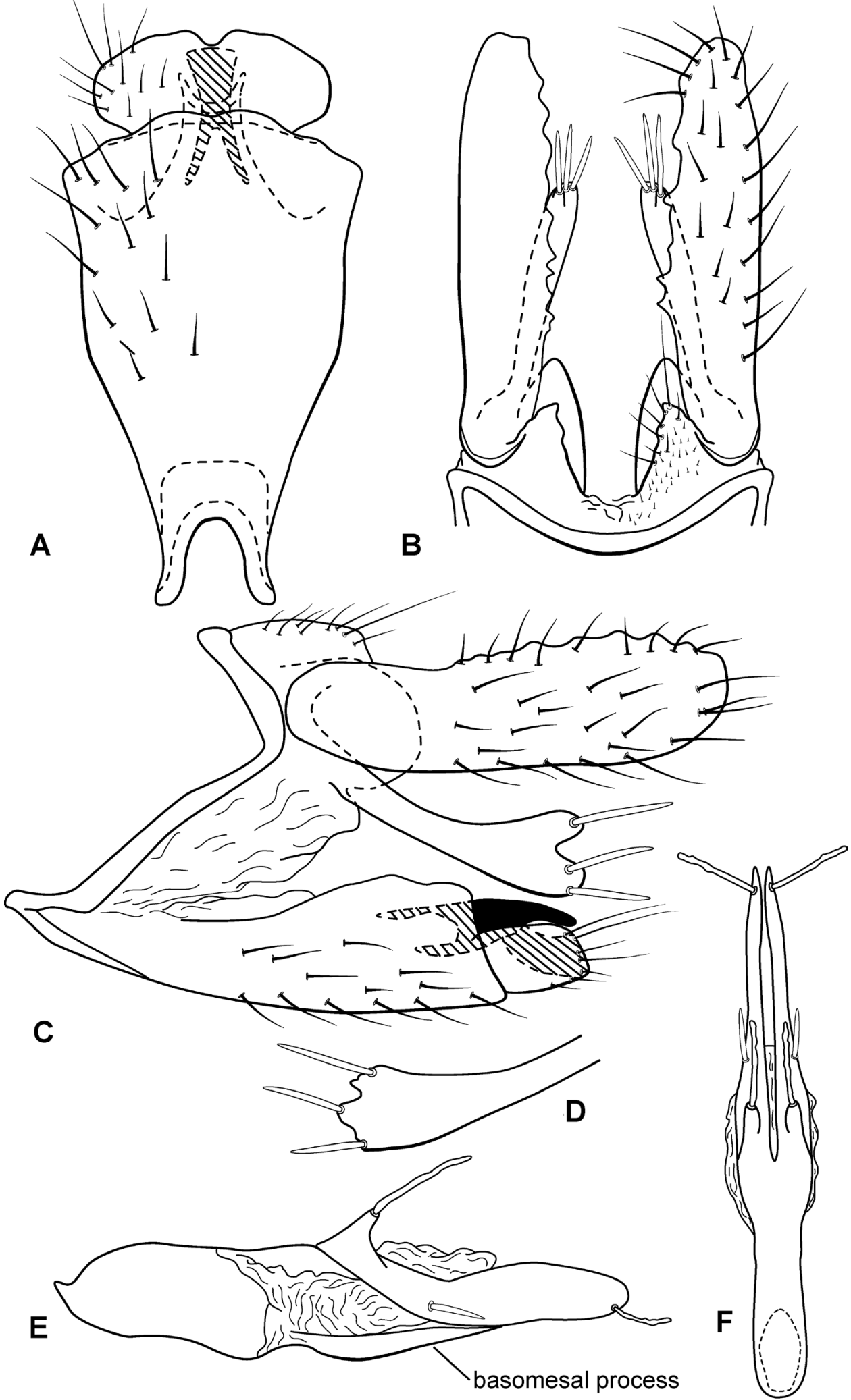

Fig. 3. Austrotinodes berthalutzae sp. nov., male genitalia. A. Ventral view. B. Dorsal view. C. Left lateral view. D. Right apex of intermediate appendage. E. Phallic apparatus, left lateral view. F. Phallic apparatus, dorsal view. 
species are short and subrectangular in lateral view. However, in A. amazonensis the posterior margin of inferior appendages possesses a wide V-shaped incision in ventral view, whereas in A. berthalutzae sp. nov. the mesal emargination is shallow.

\section{Etymology}

The specific name is a tribute to Bertha Maria Júlia Lutz, Adolfo Lutz's daughter, who was born in São Paulo in São Paulo state in 1894 and died in 1976. She became the second Brazilian woman to join the public services in Brazil, serving for four decades as a teacher and a researcher at the Museu Nacional. Bertha Lutz was internationally recognized for her valuable contribution to zoological research, specifically on Brazilian amphibians. Furthermore, she became a tireless defender of women's rights in Brazil, making an important contribution to the fight for women's suffrage in the 1930s.

\section{Material examined}

Holotype

BRAZIL: ${ }^{\lambda}$, Mato Grosso do Sul, Bonito, Hotel Cabana, Rio Formosinho, $21^{\circ} 10^{\prime} 16^{\prime \prime} \mathrm{S}, 56^{\circ} 26^{\prime} 47^{\prime \prime} \mathrm{W}$, 277 m, 8-13 Sep. 2013, A.P.M. Santos and D.M. Takiya leg. (DZRJ).

\section{Paratypes}

BRAZIL: $3 \widehat{\overbrace{}} \widehat{\jmath}$, same data as holotype (DZRJ).

\section{Description}

ADULT. Length of forewing 3.04-3.26 mm $(\mathrm{n}=4)$. In alcohol, general color brown, with golden brown sclerites; antennae stramineous, dorsum of head golden brown, with pale yellow and dark brown setae; thorax golden brown dorsally, light yellow ventrally; legs yellow, legs segments with brown setae; wings pale brown, forewing with fine pale brown setae dorsally.

WINGS. Forewing with R1 forked apically, forks II-V present; hind wing with forks II, III and V, discoidal cell absent.

Male genitalia. Segment IX deeply divided, sternum elongate; in lateral view enlarged subapically, ventral margin slightly convex; in ventral view, about 2 times as long as wide, narrow at base, enlarging apically, apical margin slightly convex. Phallic guide darkly sclerotized, elevated over inferior appendages; in lateral view, almost straight, forked at the slightly broad base, apex subacute, reaching apex of inferior appendage. Inferior appendages fused mesally, attached apicomesally on sternum IX; in lateral view short, subrectangular; in ventral view less wide than sternum IX, posterior margin slightly convex and crenulated, with shallow mesal emargination, without lateral lobes. Tergum X divided into pair of semimembranous subtriangular lobes, bearing slender dorsal setae along inner margin and a long seta at apex; in lateral view, subrectangular. Preanal appendages long, surface setose, margin crenulated, parallel-sided, apex rounded. Intermediate appendages almost $2 / 3$ length of preanal appendage; in lateral view, enlarging apically, slightly curved dorsomesally, apex enlarged, asymmetric; left appendage with bilobed apex, bearing three spine-like setae directed posterad, one in dorsal lobe and two in ventral lobe; right appendage with irregular distal margin, with three spine-like setae (asymmetry also occurs in paratypes). Phallus with sclerotized phallobase and membranous apicodorsal region; lateral process elongate, bifid; dorsal branch short, directed posterodorsoapically, with an elongate apical spine; ventral branch long, wide, rounded apically, with three spines, one near base, one positioned almost at median region, and one at apex; basomesal process elongate, narrow, darkly sclerotized, with pointed apex.

\section{Distribution}

Brazil (MS). 


\section{Austrotinodes chagasi sp. nov. urn:1sid:zoobank.org:act:99DB52C3-4BE7-4DFE-8FCB-96673F9AC866}

\section{Diagnosis}

Figs 4, 14

This species resembles $A$. bracteatus in the shape of its intermediate appendage, which is elongate, club-shaped and possesses stout spine-like setae near its apex. However, A. chagasi sp. nov. can be easily distinguished from $A$. bracteatus by its more elongate and crenulated preanal appendages, and especially by the general structure of the phallus, which has a branched lateral process, with a long finger-like ventral branch, whereas in the formerly described species the lateral process is shorter and not branched.

\section{Etymology}

The species is dedicated to the Brazilian sanitary physician, scientist and bacteriologist Carlos Justiniano Ribeiro Chagas, who was born at Oliveira in Minas Gerais state in 1879 and died in 1934. Carlos Chagas described, in 1909, the disease named after him (Chagas disease) as well as the etiological agent (Trypanosoma) and the vector (hematophagous insects, Triatoma infestans Klug, 1843). The deed of discovering all the links in the epidemiological chain of an infectious disease was absolutely unprecedented in the history of medicine.

\section{Material examined}

\section{Holotype}

BRAZIL: $\widehat{\partial}$, Espírito Santo, Santa Leopoldina, Comunidade Chaves, afluente de $2^{\mathrm{a}}$ ordem do Rio da Prata, 2002'22.9" S, 40³1'54.2" W, 592 m, 23 Mar. 2013, L.L. Dumas and J.L. Nessimian leg. (DZRJ).

\section{Paratypes}

BRAZIL: Santa Catarina: 1 Oे$^{\Uparrow}$, Blumenau, PE Spitzkopf, Ribeirão do Caeté, $27^{\circ} 00^{\prime} 22.6^{\prime \prime} \mathrm{S}, 49^{\circ} 06^{\prime} 50.4^{\prime \prime} \mathrm{W}$, 130 m, 20 Jan. 2011, J.L. Nessimian and D.M. Takiya leg. (DZRJ). — Paraná: 4 ổ, Guaraqueçaba,

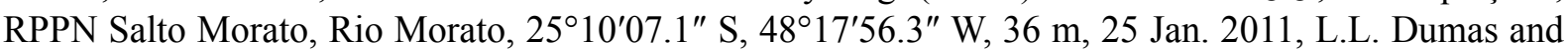

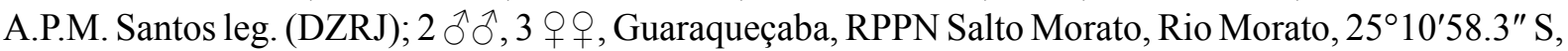

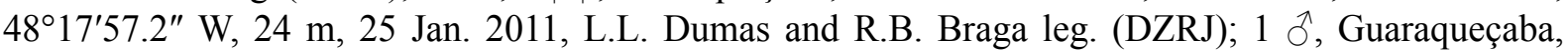
Ribeirão do Engenho, $25^{\circ} 10^{\prime} 31.0^{\prime \prime} \mathrm{S}, 48^{\circ} 22^{\prime} 16.2^{\prime \prime} \mathrm{W}, 25 \mathrm{~m}, 25$ Jan. 2011, L.L. Dumas and J.L. Nessimian

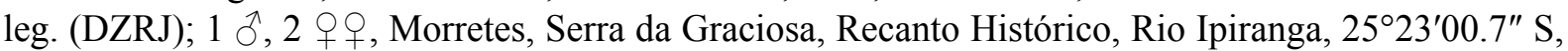

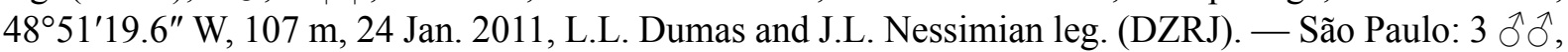
Cananéia, PE Ilha do Cardoso, Rio Perequê, $25^{\circ} 06^{\prime} 02.7^{\prime \prime} \mathrm{S}, 47^{\circ} 55^{\prime} 52.8^{\prime \prime} \mathrm{W}, 40 \mathrm{~m}, 18-23$ Oct. 2011, AP Pinto leg. (DZRJ); $2 \hat{\partial}$, Iporanga, estrada Apiaí-Iporanga, confluência do Rio Sem Fim com Rio Betari, 24³4'06.6" S, 48³9'36.6" W, 245 m, 10 Oct. 2011, G.A. Jardim and J.L. Nessimian leg.

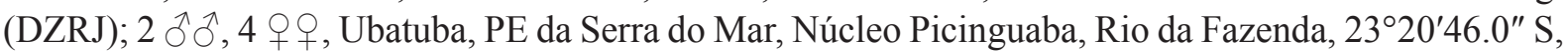
4450'59.6" W, 52 m, 2 Oct. 2009, L.L. Dumas and A.P.M. Santos leg. (DZRJ); 1 Ō, Ubatuba, PE da Serra do Mar, Núcleo Picinguaba, Casa de Farinha, Rio da Fazenda, 2320'46.0" S, 4450'59.6" W, 52 m, 31 May 2014, L.L. Dumas and J.L. Nessimian leg. (DZRJ). — Espírito Santo: 1 đ̊, Santa Teresa, Reserva Biológica Santa Lúcia, 9-10 Jan. 2003, A.L. Carvalho leg. (DZRJ); 1 ô, Alegre, Celina, PE da

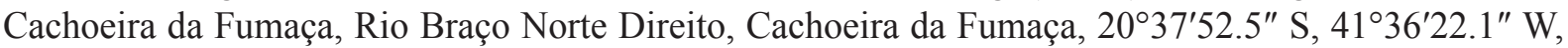
163 m, 28 Mar. 2011, L.L. Dumas and G.A. Jardim leg. (DZRJ). — Rio de Janeiro: 1 o, Angra dos Reis, Perequê, afluente de $2^{\mathrm{a}}$ ordem do Rio Mambucaba, $22^{\circ} 56^{\prime} 46.9^{\prime \prime} \mathrm{S}, 44^{\circ} 34^{\prime} 53.9^{\prime \prime} \mathrm{W}, 8 \mathrm{~m}, 19$ Mar. 2001, L.L. Dumas and J.L. Nessimian leg. (DZRJ); 1 $\widehat{\text { }}$, Angra dos Reis, Ilha Grande, riacho próximo ao aqueduto, $23^{\circ} 08^{\prime} 01.8^{\prime \prime} \mathrm{S}, 4^{\circ} 10^{\prime} 23.4^{\prime \prime} \mathrm{W}, 44 \mathrm{~m}, 10-13$ Jan. 2003, L.L. Dumas and J.L. Nessimian

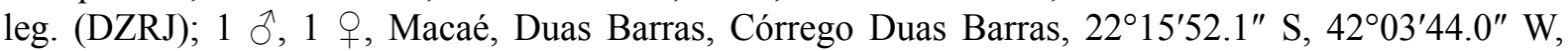

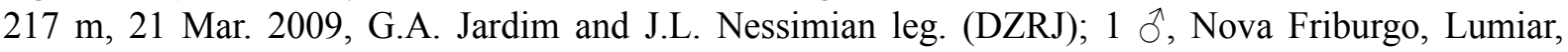

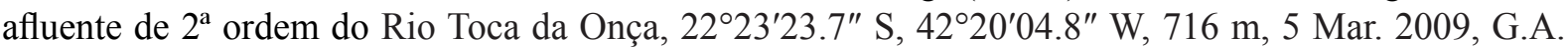



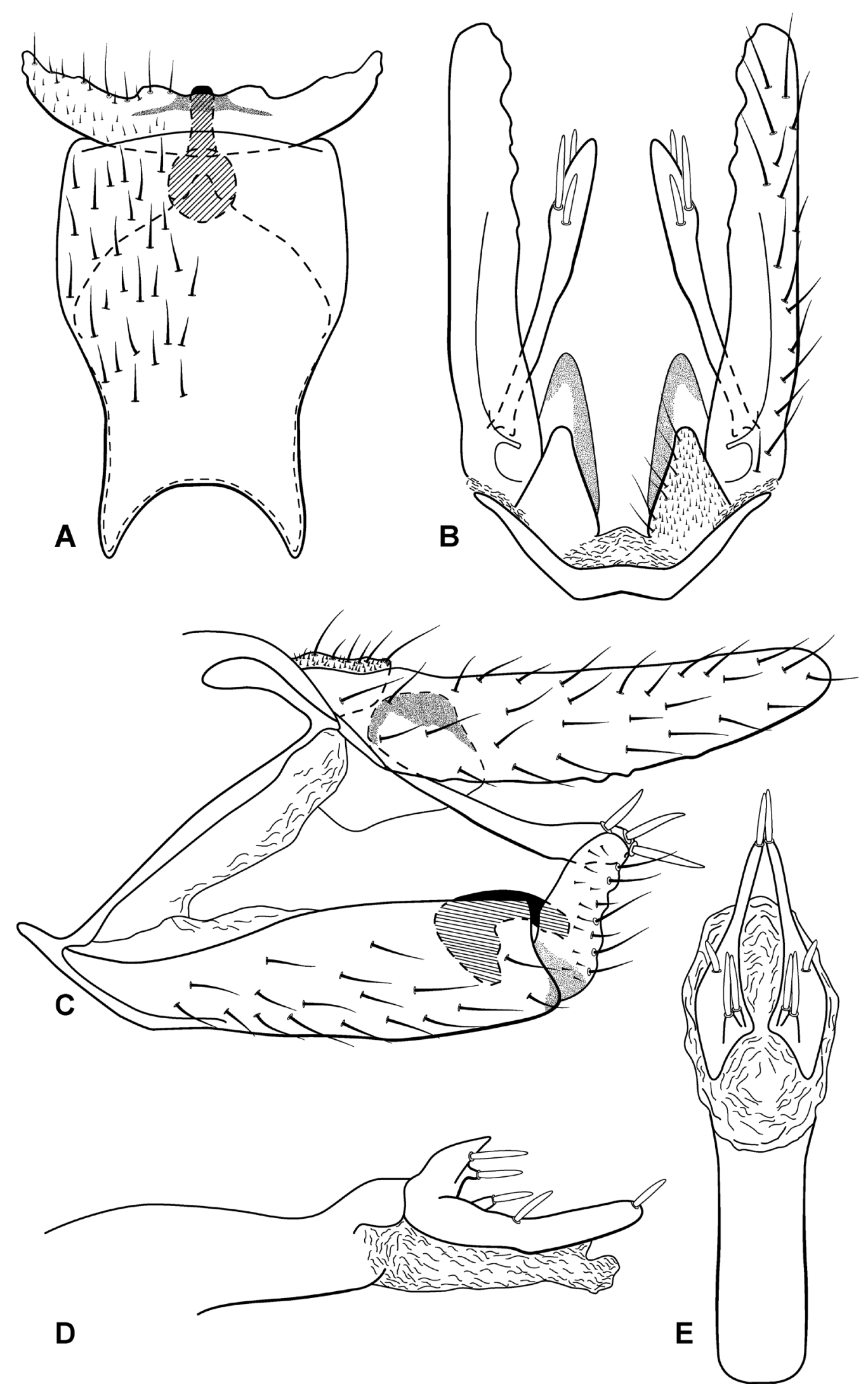

Fig. 4. Austrotinodes chagasi sp. nov., male genitalia. A. Ventral view. B. Dorsal view. C. Left lateral view. D. Phallic apparatus, left lateral view. E. Phallic apparatus, dorsal view. 
Jardim and J.L. Nessimian leg. (DZRJ); 1 đ̂, 2 q $q$, Paraty, São Gonçalo, afluente do Rio São Gonçalo,

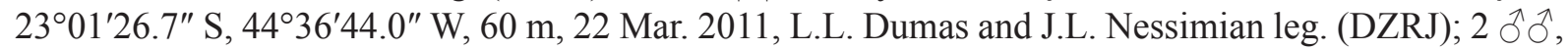

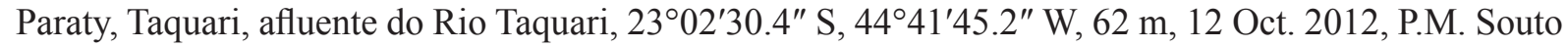
and R.S. Gonçalves leg. (DZRJ); 1 ग̃, Paraty, Perequê, afluente do Rio Mambucaba, 22 ${ }^{\circ} 56^{\prime 2} 28.4^{\prime \prime}$ S, 44³6'33.8" W, 75 m, 1 Feb. 2013, P.M. Souto, L.F.L. Silveira and J.R. Mermudes leg. (DZRJ).

\section{Description}

Adult. Length of forewing 4.00-5.60 mm $(\mathrm{n}=10)$. In alcohol, general color golden brown, with yellowish brown sclerites; antennae stramineous, dorsum of head golden brown, with pale yellow and dark brown setae; thorax golden brown dorsally, light yellow ventrally; legs yellow, legs segments with brown setae; wings pale brown, forewing with fine pale brown setae dorsally.

WINGS. Forewing with R1 forked apically, forks II-V present; hind wing with forks II, III and V, discoidal cell absent.

MALE GENITALIA. Segment IX deeply divided, sternum elongate; in lateral view, narrow basally, margins parallel-sided from distal half, ventral margin curved basally; in ventral view, about 2 times as long as wide, enlarged in distal half, apical margin convex. Phallic guide darkly sclerotized, not highly elevated; in lateral view, arched, base broad, apex rounded, reaching middle of inferior appendage. Inferior appendages fused mesally, attached apicomesally on sternum IX; in lateral view, elongate, ovate, apex rounded; in ventral view, lateral lobes very elongate, directed posterolaterally, posterior margin concave, crenulated. Tergum X divided into pair of semimembranous subtriangular lobes, lobes bulbous, bearing slender setae along inner margin; in lateral view, subrectangular. Preanal appendages long, surface setose, margin crenulated, parallel-sided, apex rounded. Intermediate appendages long, narrow, approximately $2 / 3$ length of preanal appendage; in lateral view, club-shaped, enlarged apically, with 3 stout spine-like setae at apex (subapically positioned in dorsal view). Phallus with sclerotized phallobase and membranous apicoventral region; lateral process moderately elongate, bifid; dorsal branch short, robust, pointed posterodorsoapically, with 2 spines on distal half, the shorter one positioned on small projection; ventral branch long, finger-like in lateral view, wider at base in dorsal view, rounded apically, with 3 spines, 1 positioned on small projection near base, 1 almost at median region, and 1 at apex; without basomesal process.

\section{Distribution}

Brazil (ES, RJ, SC, SP, PR).

$$
\begin{gathered}
\text { Austrotinodes costalimai sp. nov. } \\
\text { urn:Isid:zoobank.org:act:B9E2F5A8-6411-4C93-847C-8EF4B6D50BA3 }
\end{gathered}
$$

Figs 5, 14

\section{Diagnosis}

Austrotinodes costalimai sp. nov. resembles $A$. lattesi $\mathrm{sp}$. nov. and $A$. bracteatus in the general shape of its phallic apparatus, which are short and elongate ovate. In the new species, the lateral process of the phallus has 2 extremely long spines near its apex, whereas in the other species none of the spines are so elongate. Additionally, the intermediate appendages of $A$ costalimai sp. nov. and A. lattesi sp. nov. are curved and rod-like, whereas in A. bracteatus they are club-like and not curved. In A. costalimai sp. nov. the intermediate appendages are abruptly curved dorsad near its apex, forming almost a right angle, and bear 2 ventral spine-like setae at its apical third; in A. lattesi sp. nov. they are gently curved dorsad, forming an obtuse angle, and bear 1 mesolateral seta. 

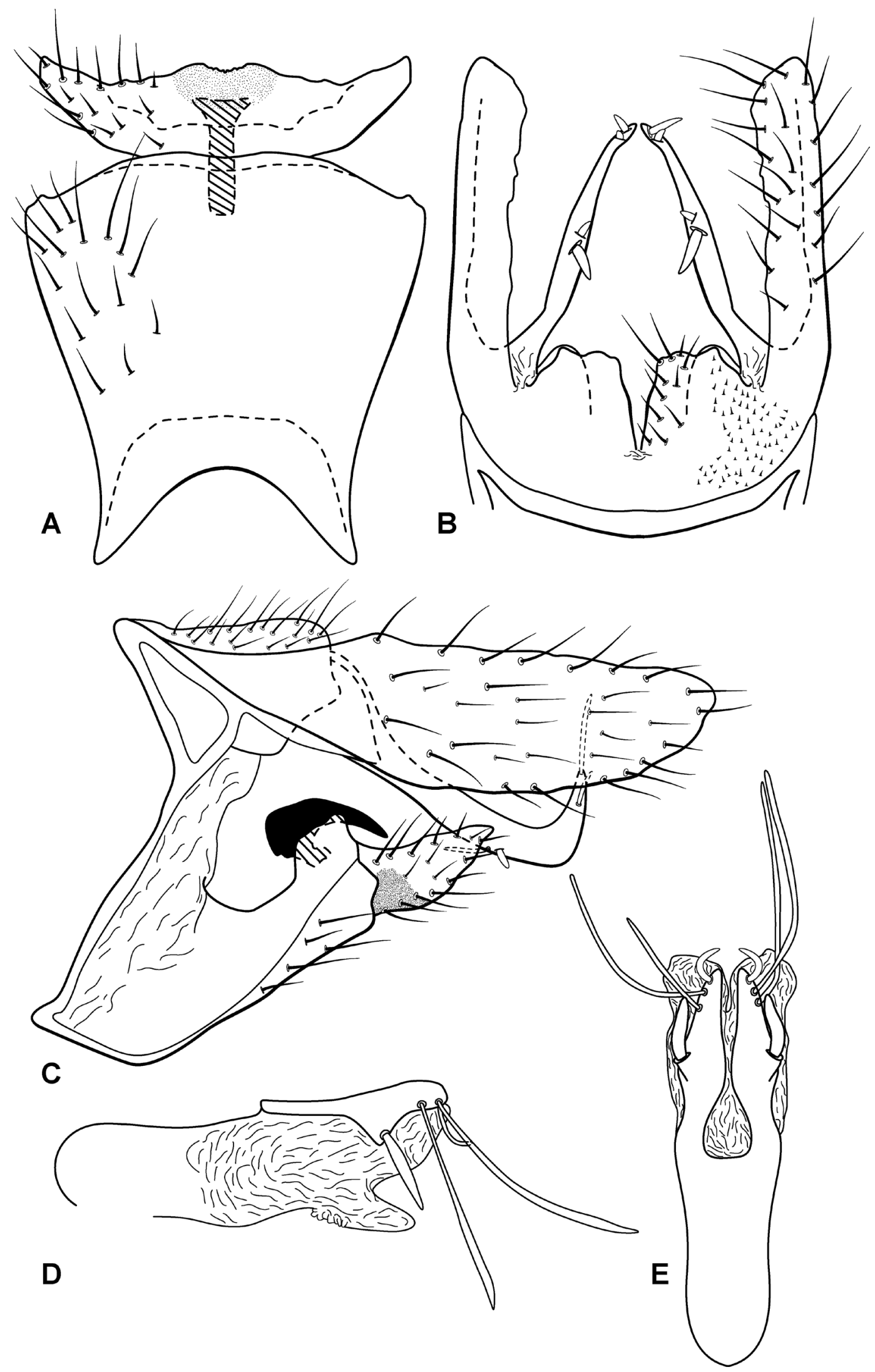

Fig. 5. Austrotinodes costalimai sp. nov., male genitalia. A. Ventral view. B. Dorsal view. C. Left lateral view. D. Phallic apparatus, left lateral view. E. Phallic apparatus, dorsal view. 


\section{Etymology}

The species is dedicated to one of the foremost Brazilian entomologists, Angelo Moreira da Costa Lima, who was born at Rio de Janeiro in Rio de Janeiro state in 1887 and died in 1964. Costa Lima made many contributions to studies of insects, being considered the father of Brazilian entomology. Among his most important works are the "Terceiro Catálogo", which was one of the most consulted works on plant-insect associations, and the book "Insetos do Brasil", published in eleven volumes and regularly consulted until today.

\section{Material examined}

\section{Holotype}

BRAZIL: Ō, São Paulo, Iporanga, PE Intervales, Córrego do Mirante, 24¹6'46.4" S, 48²4'45.7" W, 803 m, 8 Oct. 2011, L.L. Dumas and J.L. Nessimian leg. (DZRJ).

\section{Paratypes}

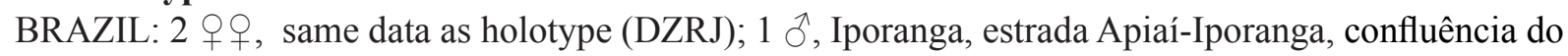
Rio Sem Fim com Rio Betari, 24³4'06.6" S, 48³9'36.6” W, 245 m, 10 Oct. 2011, G.A. Jardim and J.L. Nessimian leg. (DZRJ).

\section{Description}

AduLt. Length of forewing 4.25-5.50 mm $(\mathrm{n}=2)$. In alcohol, general color golden brown, with golden brown sclerites; antennae stramineous, dorsum of head golden brown, with pale yellow and dark brown setae; thorax golden brown dorsally, light yellow ventrally; legs yellow, legs segments with brown setae; wings pale brown, forewing with fine pale brown setae dorsally. Wing venation typical for genus; forewing with R1 forked apically, forks II-V present; hind wing with forks II, III and V, discoidal cell absent.

Male genitalia. Segment IX deeply divided, sternum elongate; in lateral view, sternum enlarged at apex, ventral margin curved basally forming an obtuse angle; in ventral view, about as long as wide, constricted basally, apical margin slightly convex. Phallic guide darkly sclerotized, elevated over inferior appendages; in lateral view, strongly arched, base broad, apex subacute, reaching base of inferior appendage. Inferior appendages fused mesally, attached apicomesally on sternum IX; in lateral view, elongate, subtriangular; in ventral view, lateral lobes elongate, directed posterolaterally, posterior margin slightly concave, crenulated. Tergum $\mathrm{X}$ divided into pair of semimembranous quadrate lobes, lobes bulbous, bearing slender dorsal setae; in lateral view, subrectangular. Preanal appendages long, large, surface setose, margin slightly crenulated, parallel-sided, apex rounded. Intermediate appendages long, approximately $3 / 4$ length of preanal appendage; in lateral view, cylindrical, margins parallel-sided, strongly curved dorsad near apex, with 2 ventral spine-like setae at apical third (setae opposite-sided, one 4 times longer than other), 1 short preapical spine-like seta, and 1 apical long spine-like seta. Phallus with sclerotized phallobase and membranous apicalventral region; lateral process short, elongate oval, widest mesally, with 1 long, stout, midlateral spine and a row of 3 slender apical spines, the more apical one very short compared to subapical ones; lateral process, in dorsal view, U-shaped; without basomesal process.

\section{Distribution}

Brazil (SP). 


\section{Austrotinodes cruzi sp. nov. urn:lsid:zoobank.org:act:DE6F6AE4-3650-49DC-B099-DEAF33FE4AD7}

Figs 6, 14

\section{Diagnosis}

Austrotinodes cruzi sp. nov. can be distinguished from all other species of the genus by the unusual shape of the intermediate appendages, which are very elongate and boomerang-like, and by the phallus, which has a short lateral process, hood-like when viewed laterally.

\section{Etymology}

The species is dedicated to the Brazilian physician, scientist, epidemiologist and bacteriologist Oswaldo Gonçalves Cruz, who was born at São Luiz do Paraitinga in São Paulo state in 1872 and died in 1917. Oswaldo Cruz was the mentor in an important sanitary campaign in Rio de Janeiro, which aimed at controlling the bubonic plague, yellow fever and smallpox. These diseases were raging all over the city, at the turn of the $20^{\text {th }}$ century, decimating the population. He also was the founder of an important research institute, named after him.

\section{Material examined}

\section{Holotype}

BRAZIL: $\widehat{\partial}$, Espírito Santo, Alegre, Celina, PE da Cachoeira da Fumaça, Córrego da Graminha, 20³7'55.0" S, 41³6'26.3" W, 477 m, 28 Mar. 2011, L.L. Dumas and G.A. Jardim leg. (DZRJ).

\section{Description}

ADULT. Length of forewing $4.75 \mathrm{~mm}(\mathrm{n}=1)$. In alcohol, general color golden brown, with golden brown sclerites; antennae light yellow, dorsum of head dark golden brown, with pale yellow and dark brown setae; thorax golden brown dorsally, light yellow ventrally; legs yellow, legs segments with brown setae; wings pale brown, forewing with fine pale brown setae dorsally. Wings. Forewing with R1 forked apically, forks II-V present; hind wing with forks II, III and V, discoidal cell absent.

Male Genitalia. Segment IX deeply divided, sternum elongate; in lateral view, narrow basally, enlarging apically, ventral margin slightly convex; in ventral view, about 1.5 times as long as wide, constricted medially, apical margin convex. Phallic guide darkly sclerotized, elevated over inferior appendages; in lateral view, strongly arched, base moderately broad, apex subacute, reaching middle of inferior appendage. Inferior appendages fused mesally, attached apicomesally on sternum IX; in lateral view, elongate, subtriangular, apex rounded; in ventral view, lateral lobes very elongate, directed posterolaterally, posterior margin concave, not crenulated, with mesal emargination. Tergum X divided into pair of semimembranous oval lobes, lobes bulbous, bearing slender setae along inner margin; in lateral view, subrectangular. Preanal appendages long, surface setose, margin crenulated, wider at base, tapering apically, apex rounded; in dorsal view, with a small invagination near apex at inner margin. Intermediate appendages very long, bifid; in lateral view, boomerang-like, ventral branch strongly curved apically, reaching middle of phallic guide, dorsal branch directed posterad, bearing 1 stout setae at apex and small dorsal pointed projection near base. Phallus with sclerotized phallobase and membranous apicoventral region; lateral process short, with moderately produced apical finger-like projection bearing apical spine; base with 2 spines ventrobasally (only 1 spine visible in lateral view); without basomesal process.

\section{Distribution}

Brazil (ES). 

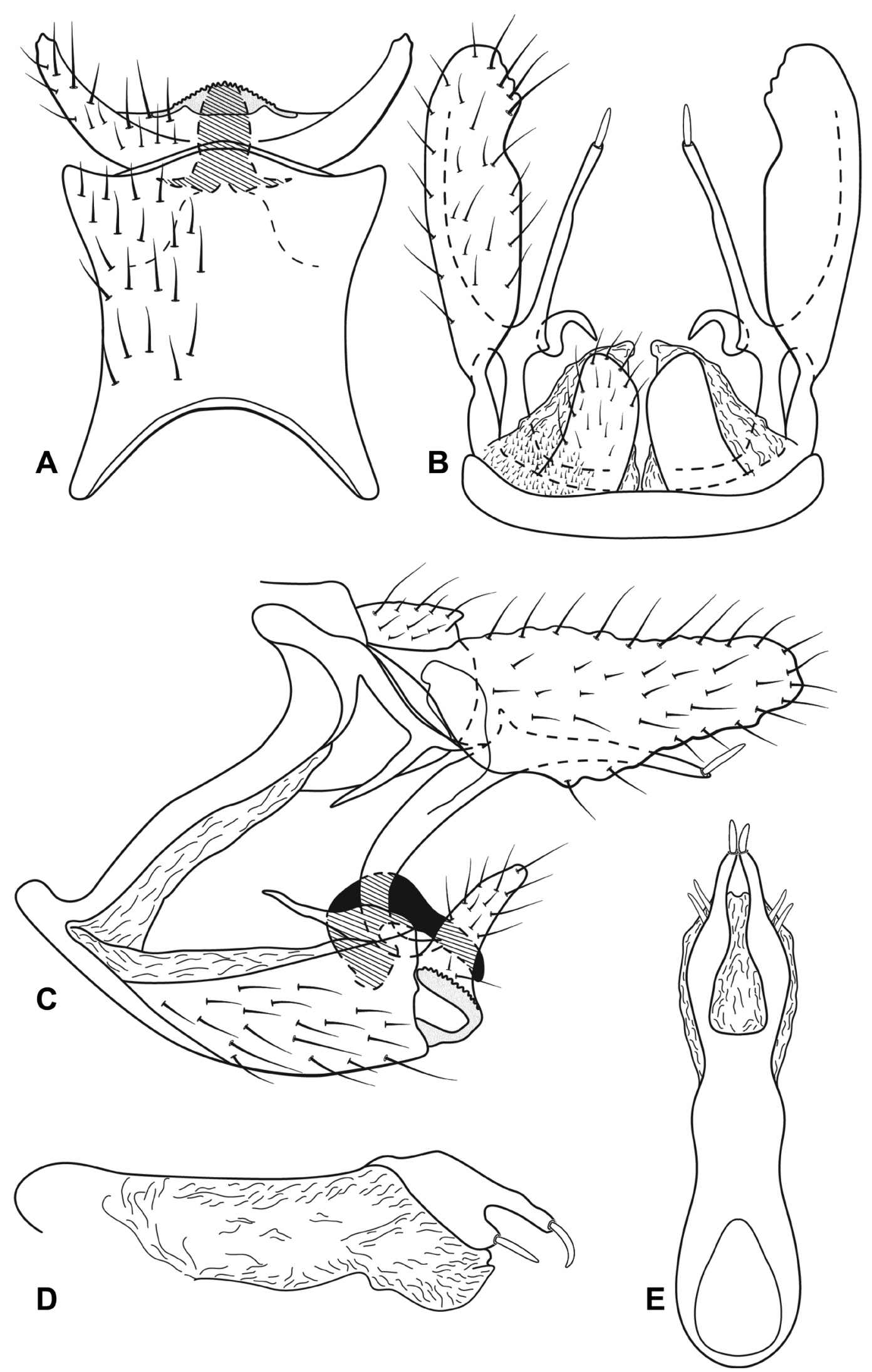

Fig. 6. Austrotinodes cruzi sp. nov., male genitalia. A. Ventral view. B. Dorsal view. C. Left lateral view. D. Phallic apparatus, left lateral view. E. Phallic apparatus, dorsal view. 


\section{Austrotinodes donagrazielae sp. nov. urn:1sid:zoobank.org:act:FA23A95D-2D10-40E4-BE23-1B694EBF901C}

Figs 7, 14

\section{Diagnosis}

Austrotinodes donagrazielae sp. nov. belongs to the taquaralis Group, as mentioned before. All species of this group has a row of three stout ventrolateral spines on dorsal branch of lateral process of the phallus; however, only $A$. donagrazielae sp. nov. has the last spine subapically positioned, while in the other three species it is apically positioned. Additionally, the invagination of the anterior margin of segment IX in the species described here is larger, U-shaped, while in the other species of the taquaralis Group it is shallower, V-shaped. The phallic guide is also more robust than in A. absaberi sp. nov., A. gusmaoi sp. nov. and A. taquaralis Thomson \& Holzenthal, 2010.

\section{Etymology}

The species is dedicated to the Brazilian botanist Graziela Maciel Barroso, who was born at Corumbá in Mato Grosso do Sul state in 1912 and died in 2003. Graziela Barroso was a leading authority on the flora of Brazil, and published a three-volume "Sistemática de Angiospermas do Brasil", which is an international reference on the subject. Dona Graziela, the cherished name by which she was known, is recognized as the First Lady of Brazilian Botany, being the first woman who graduated from a course of natural history in Brazil.

\section{Material examined}

\section{Holotype}

BRAZIL: đ̃, São Paulo, São José do Barreiro, Lajeado, Cachoeira do Príncipe, 22 $42^{\prime} 48.9^{\prime \prime}$ S, 44³7'26.3" W, 1557 m, 17 Dec. 2010, L.L. Dumas leg. (DZRJ).

\section{Paratypes}

BRAZIL: 4 q $ᄋ$, same data as holotype (DZRJ); 1 ${ }^{\lambda}$, São José do Barreiro, riacho de $1^{\mathrm{a}}$ ordem,

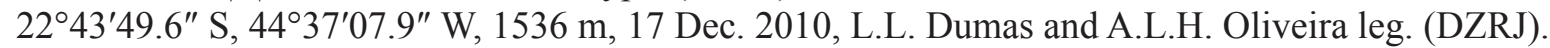

\section{Description}

ADULT. Length of forewing 5.75-5.90 mm $(\mathrm{n}=2)$. In alcohol, general color golden brown, with golden brown sclerites; antennae stramineous, dorsum of head golden brown, with pale yellow and dark brown setae; thorax golden brown dorsally, light yellow ventrally; legs yellow, legs segments with brown setae; wings pale brown, forewing with fine pale brown setae dorsally.

WINGS. Forewing with R1 forked apically, forks II-V present; hind wing with forks II, III and V, discoidal cell absent.

Male genitalia. Segment IX deeply divided, sternum extremely elongate; in lateral view, narrow at base, enlarging apically, ventral margin slightly convex; in ventral view, about 1.5 times as long as wide, enlarging apically, apical margin slightly convex. Phallic guide darkly sclerotized, not highly elevated; in lateral view, strongly arched, base broad, apex subacute, reaching middle of inferior appendage. Inferior appendages fused mesally, attached apicomesally on sternum IX; in lateral view, stout, ovate, apex rounded; in ventral view, lateral lobes subquadrate, directed posterolaterally, posterior margin convex, not crenulated, with mesal emargination. Tergum X divided into pair of semimembranous ovate lobes, lobes bulbous, bearing slender dorsal setae; in lateral view, subrectangular, elongate. Preanal appendages long, surface setose, margin crenulated, almost parallel-sided, apex rounded. Intermediate appendages long, approximately $3 / 4$ length of preanal appendage; in lateral view, wider at base, tapering 

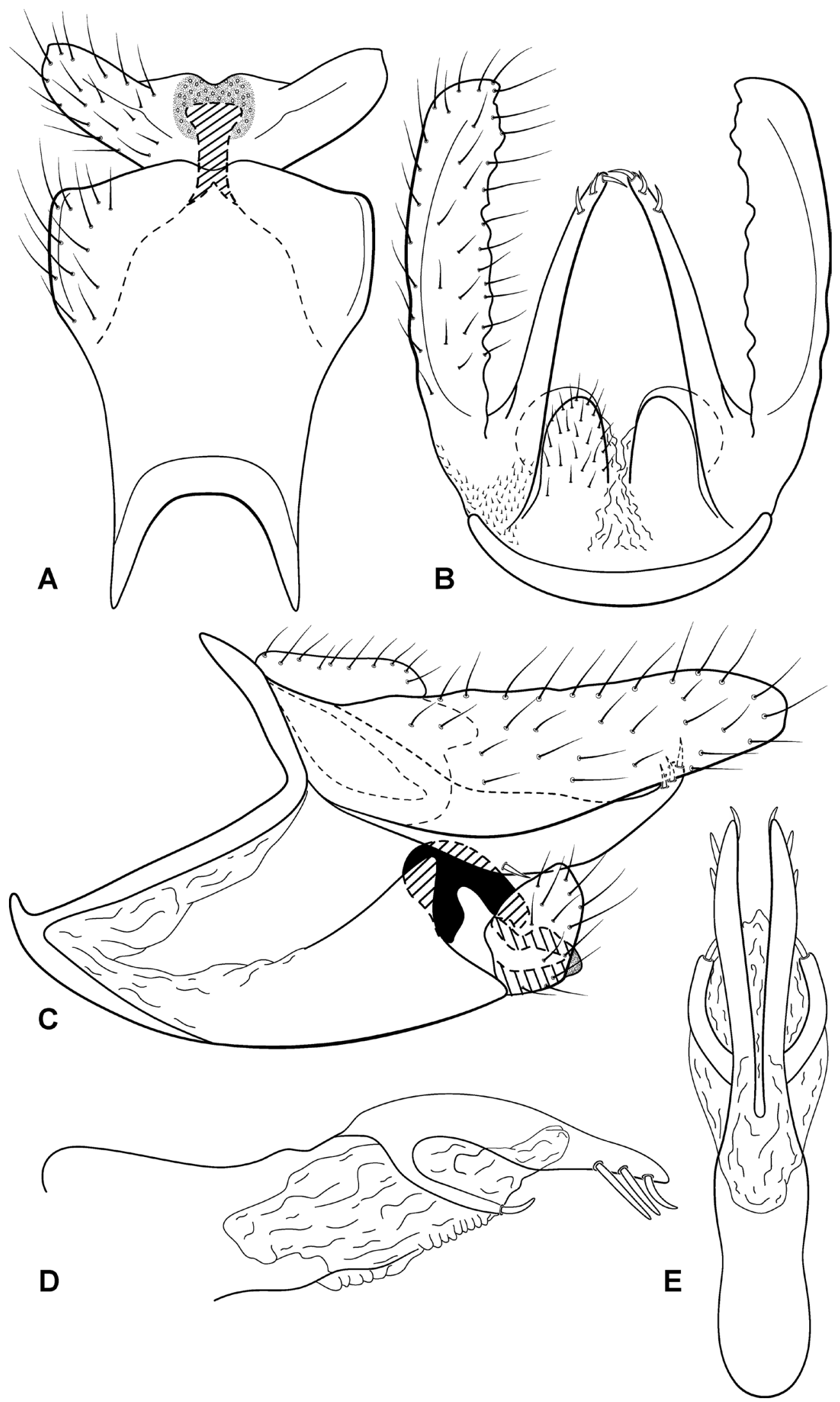

Fig. 7. Austrotinodes donagrazielae sp. nov., male genitalia. A. Ventral view. B. Dorsal view. C. Left lateral view. D. Phallic apparatus, left lateral view. E. Phallic apparatus, dorsal view. 
to apex, curved dorsad, with 3 spine-like setae apically and 1 seta mesoventrally. Phallus with sclerotized phallobase and membranous apical region; lateral process very elongate, bifid; dorsal branch long, wide, with row of 3 stout ventral spines subapically, ventral branch shorter, long, narrow, with 1 apical spine; without basomesal process.

\section{Dsitribution}

Brazil (SP).

$$
\begin{gathered}
\text { Austrotinodes gusmaoi sp. nov. } \\
\text { urn:1sid:zoobank.org:act:3FC887CC-9311-4F83-9FC7-A67AA5B85B7A }
\end{gathered}
$$

Figs 8,14

\section{Diagnosis}

This species is most similar to A. absaberi sp. nov., A. donagrazielae sp. nov. and A. taquaralis, belonging to the taquaralis Group, as discussed previously. This species can be distinguished from all other members of the taquaralis Group by the posterior margin of sternum IX strongly convex, the preanal appendages with crenulated margins and by the very elongated lateral lobes of inferior appendages. Additionally, the more robust phallic guide and the presence of a tuft of small mesodorsal microsetae at intermediate appendages are useful characters to diagnose $A$. gusmaoi sp. nov.

\section{Etymology}

The species is dedicated to the Brazilian priest and inventor Bartolomeu de Lourenço Gusmão, who was born at Santos in São Paulo state in 1685 and died in 1724. Bartolomeu de Gusmão was the first Brazilian inventor and scientist, famous for the creation in 1709 of the hot air balloon.

\section{Material examined}

\section{Holotype}

BRAZIL: Õ, São Paulo: Salesópolis, Estação Biológica da Boracéia, alojamento, 23³9'14.7" S, 4553'22.1" W, 831 m, 28 Jan. 2011, L.L. Dumas and A.P.M. Santos leg. (DZRJ).

\section{Description}

ADULT. Length of forewing $5.15 \mathrm{~mm}(\mathrm{n}=1)$. In alcohol, general color golden brown, with golden brown sclerites; antennae stramineous, dorsum of head golden brown, with pale yellow and dark brown setae; thorax golden brown dorsally, light yellow ventrally; legs yellow, legs segments with brown setae; wings pale brown, forewing with fine pale brown setae dorsally.

WINGS. Forewing with R1 forked apically, forks II-V present; hind wing with forks II, III and V, discoidal cell absent.

MALE GENITALIA. Segment IX deeply divided, sternum elongate; in lateral view, narrow basally, enlarging apically, ventral margin slightly convex; in ventral view, about 2 times as long as wide, enlarging apically, apical margin strongly convex. Phallic guide darkly sclerotized, not highly elevated; in lateral view, arched, base broad, apex rounded, reaching middle of inferior appendage. Inferior appendages fused mesally, attached apicomesally on sternum IX; in lateral view, elongate, subtriangular, apex rounded; in ventral view, lateral lobes very elongate, directed posterolaterally, posterior margin concave, not crenulated, with mesal emargination. Tergum X divided into pair of semimembranous oval lobes, lobes bulbous, bearing slender dorsal setae; in lateral view, ovate, elongate. Preanal appendages long, surface setose, margin slightly crenulated, wider at base, tapering apically, apex rounded. Intermediate appendages long, approximately $3 / 4$ length of preanal appendage; in lateral view, wide at base, tapering 

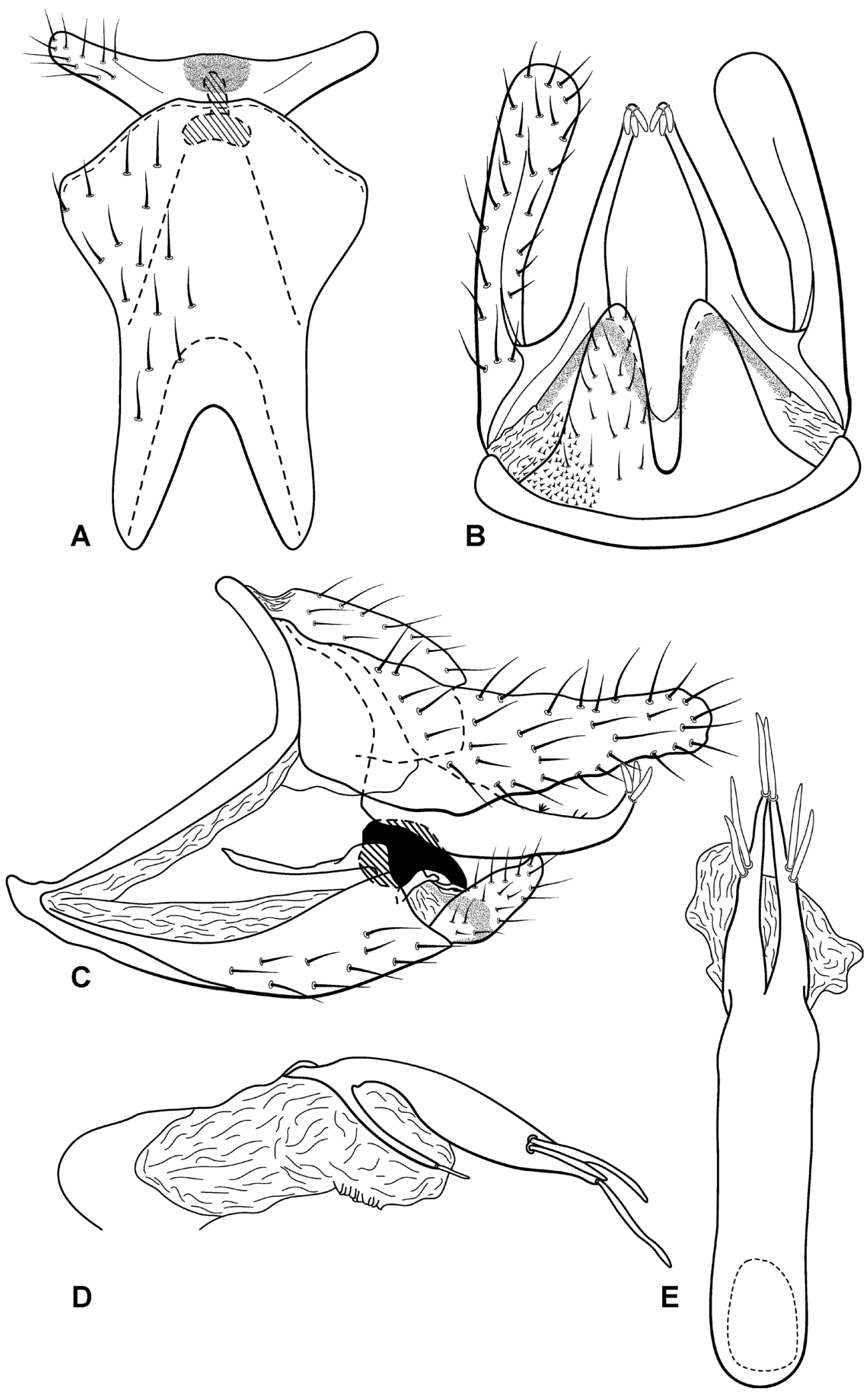

Fig. 8. Austrotinodes gusmaoi sp. nov., male genitalia. A. Ventral view. B. Dorsal view. C. Left lateral view. D. Phallic apparatus, left lateral view. E. Phallic apparatus, dorsal view. 
apically, curved dorsad near apex, with 3 spine-like setae at apex; tuft of small microsetae mesodorsally. Phallus with sclerotized phallobase and membranous apicoventral region; lateral process elongate, bifid; dorsal branch long, wide, with 2 spines at apical third and 1 long spine at apex; ventral branch narrow, with 1 apical spine; without basomesal process.

\section{Distribution}

Brazil (SP).

$$
\begin{aligned}
& \text { Austrotinodes lattesi sp. nov. } \\
& \text { urn:lsid:zoobank.org:act:2CEBC5A7-3BCE-4A85-B74D-3F8B4E7E80E1 }
\end{aligned}
$$

Figs 9,14

\section{Diagnosis}

This species is most similar to A. belchiores Thomson \& Holzenthal, 2010, resembling it in the shape of the elongate intermediate appendages. While in $A$. belchiores the intermediate appendages are bifid basally, with dorsal and basoventral branches, in the new species they are not branched, the basoventral branch lacking. Additionally, the species can be easily distinguished by the structure of the phallus, which has an ovate lateral process in $A$. lattesi sp. nov., while in $A$. belchiores it is elongate and bifid. The phallic guide is also less robust and more hook-like in the new species.

\section{Etymology}

The species is dedicated to the Brazilian physicist Cesare Mansueto Giulio Lattes, who was born at Curitiba in Paraná state in 1924 and died in 2005. César Lattes was one of the most distinguished and honored Brazilian physicists, and his work was fundamental for the development of atomic physics. He was one of the discoverers of the Pion (pi meson), a subatomic particle, and one of the main personalities behind the creation of Conselho Nacional de Desenvolvimento Científico e Tecnológico (CNPq) and Centro Brasileiro de Pesquisas Físicas (CBPF).

\section{Material examined}

\section{Holotype}

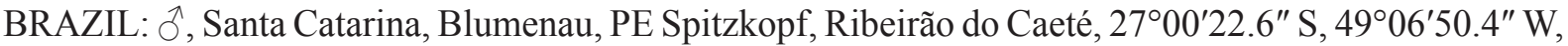
130 m, 22 Jan. 2011, D.M. Takiya and A.P.M. Santos leg. (DZRJ).

\section{Paratypes}

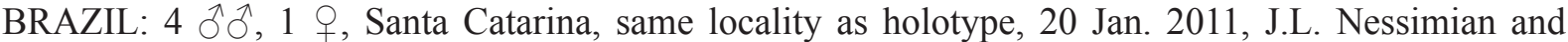
D.M. Takiya leg. (DZRJ); 1 Õ, 14 qq, same locality, 19 Jan. 2011, J.L. Nessimian and A.P.M. Santos

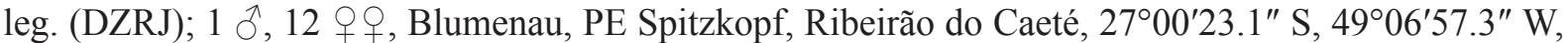
139 m, 20 Jan. 2011, J.L. Nessimian and A.P.M. Santos leg. (DZRJ); 1 స, 6 o $q$, Blumenau, PE

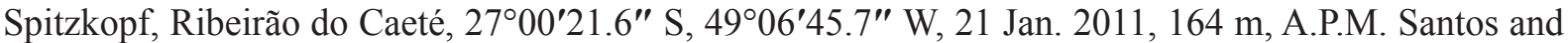
J.L. Nessimian leg. (DZRJ). - São Paulo: 1 đ̄, Cananéia, PE Ilha do Cardoso, Rio Perequê, $25^{\circ} 06^{\prime} 02.7^{\prime \prime}$ S, $47^{\circ} 55^{\prime} 52.8^{\prime \prime} \mathrm{W}, 40 \mathrm{~m}, 18-23$ Oct. 2011, A.P. Pinto leg. (DZRJ); 1 Ỗ, Iporanga, PE Turístico do Alto Ribeira, Núcleo Ouro Grosso, Rio Ouro Grosso, 24³2'44.0" S, 4840'52.4" W, 238 m, 10 Oct. 2011, L.L. Dumas and N. Ferreira Jr leg. (DZRJ).

\section{Description}

ADULt. Length of forewing 4.10-4.75 mm $(\mathrm{n}=10)$. In alcohol, general color yellowish brown, with golden brown sclerites; antennae stramineous, dorsum of head golden brown, with pale yellow and dark brown setae; thorax and legs yellow, legs segments with brown setae; wings pale yellow, forewing with fine pale yellow setae dorsally. 

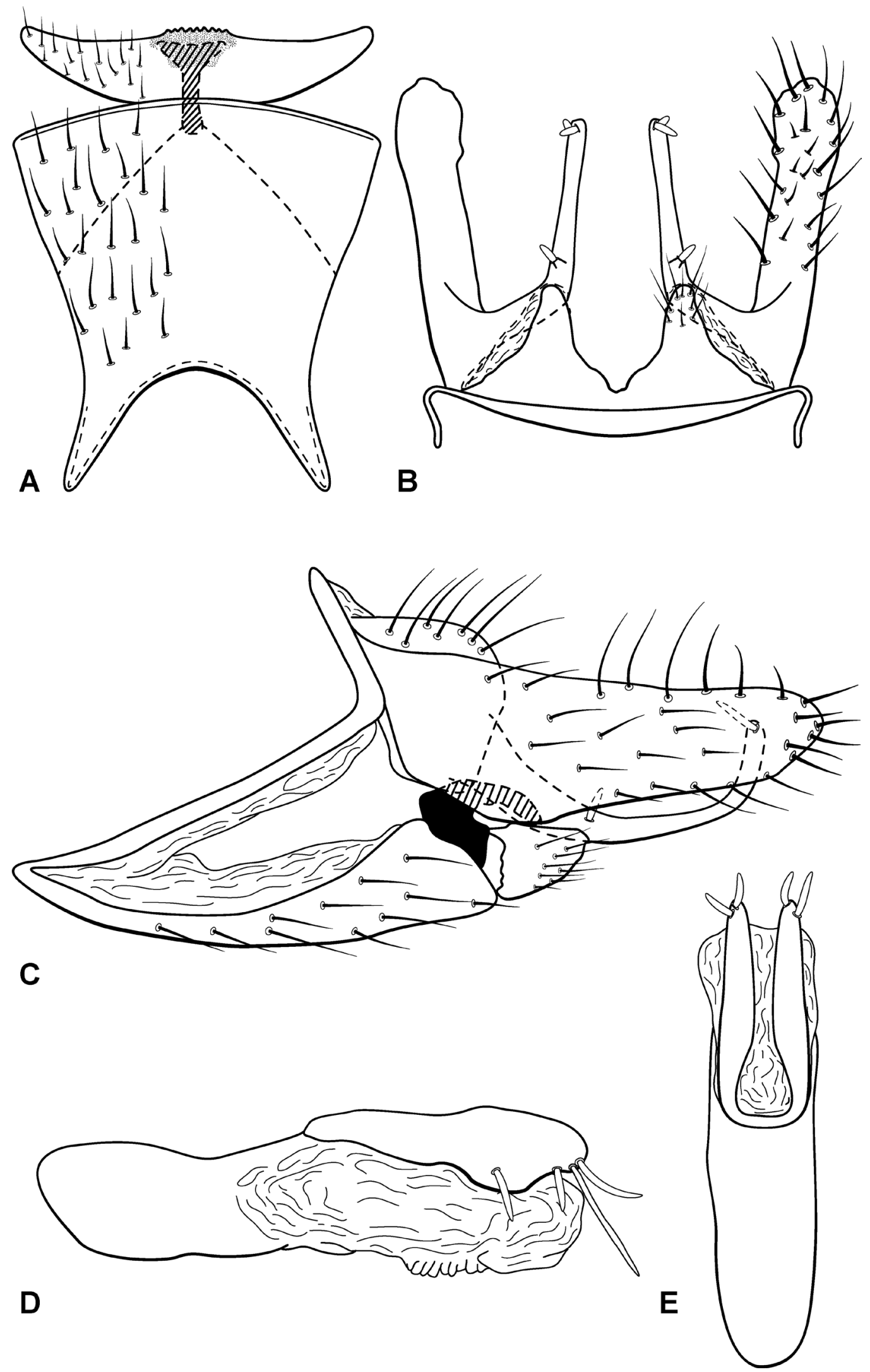

Fig. 9. Austrotinodes lattesi sp. nov., male genitalia. A. Ventral view. B. Dorsal view. C. Left lateral view. D. Phallic apparatus, left lateral view. E. Phallic apparatus, dorsal view. 
WINGS. Forewing with R1 forked apically, forks II-V present; hind wing with forks II, III and V, discoidal cell absent.

Male Genitalia. Segment IX deeply divided, sternum elongate; in lateral view, narrow basally, enlarging apically, ventral margin slightly convex; in ventral view, little longer than wide, narrow at base, enlarging to apex, apical margin slightly convex. Phallic guide darkly sclerotized, elevated over inferior appendages; in lateral view, strongly arched, base broad, apex rounded, reaching middle of inferior appendage. Inferior appendages fused mesally, attached apicomesally on sternum IX; in lateral view, short, subrectangular, apex rounded; in ventral view, lateral lobes moderately elongate, directed posterolaterally, posterior margin slightly concave, not crenulated. Tergum X divided into pair of semimembranous subtriangular lobes, lobes bulbous, bearing slender setae along inner margin; in lateral view, subrectangular. Preanal appendages long, surface setose, margin slightly crenulated, wider at base, gently tapering apically, apex rounded. Intermediate appendages long, narrow, almost same length as preanal appendage; in lateral view, rod-like, strongly curved dorsad, with 1 stout mesal seta and 1-2 stout subapical setae. Phallus with sclerotized phallobase and membranous apical region; lateral process short, elongate oval, widest subapically, with 1 spine at apical third and a row of 3 spines at apex, the mesal one 2 times longer than the others; in dorsal view U-shaped, elongate, with only 2 apical spines visible; without basomesal process.

\section{Distribution}

Brazil (SC, SP).

\section{Austrotinodes lenti sp. nov. urn:1sid:zoobank.org:act:3F6DE9B2-F30D-4178-8CD3-AD86FF898813} Figs 10,14

\section{Diagnosis}

Austrotinodes lenti sp. nov. resembles A. chihuahua Flint \& Denning, 1989 in the structure of the moderately elongate club-like intermediate appendages with 3 spine-like setae near its apex. This species is easily diagnosed by the unusual bifid shape of the lateral process of the phallic apparatus, with a short, stout dorsal branch bearing 3 spines at its anterior margin, and a long, slender ventral branch with an apical, very elongate rugose, spine-like seta.

\section{Etymology}

This species is dedicated to the Brazilian medical zoologist and entomologist Herman Lent, who was born in Rio de Janeiro in Rio de Janeiro state in 1923 and died in 2004. Herman Lent dedicated himself to studying the vectors of Chagas' disease, becoming one of the greatest triatomine specialists in the world, and publishing more than 200 scientific papers.

\section{Material examined}

\section{Holotype}

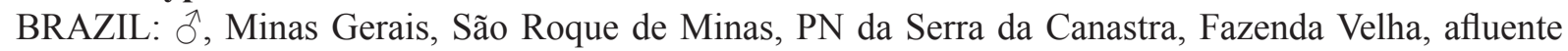
do Ribeirão das Posses (Córrego dos Pombos), 20¹4'56.60"S, 46³8'04,90" W, 997 m, 2 Apr. 2014, J.L. Nessimian, A.L.H. Oliveira, L.L. Dumas and S.P. Gomes leg. (DZRJ).

\section{Description}

ADULT. Length of forewing $4.00 \mathrm{~mm}(\mathrm{n}=1)$. In alcohol, general color golden brown, with golden brown sclerites; antennae stramineous, dorsum of head dark golden brown, with pale yellow and dark brown setae; thorax golden brown dorsally, light yellow ventrally; legs yellow, legs segments with brown setae; wings pale brown, forewing with fine pale brown setae dorsally. 

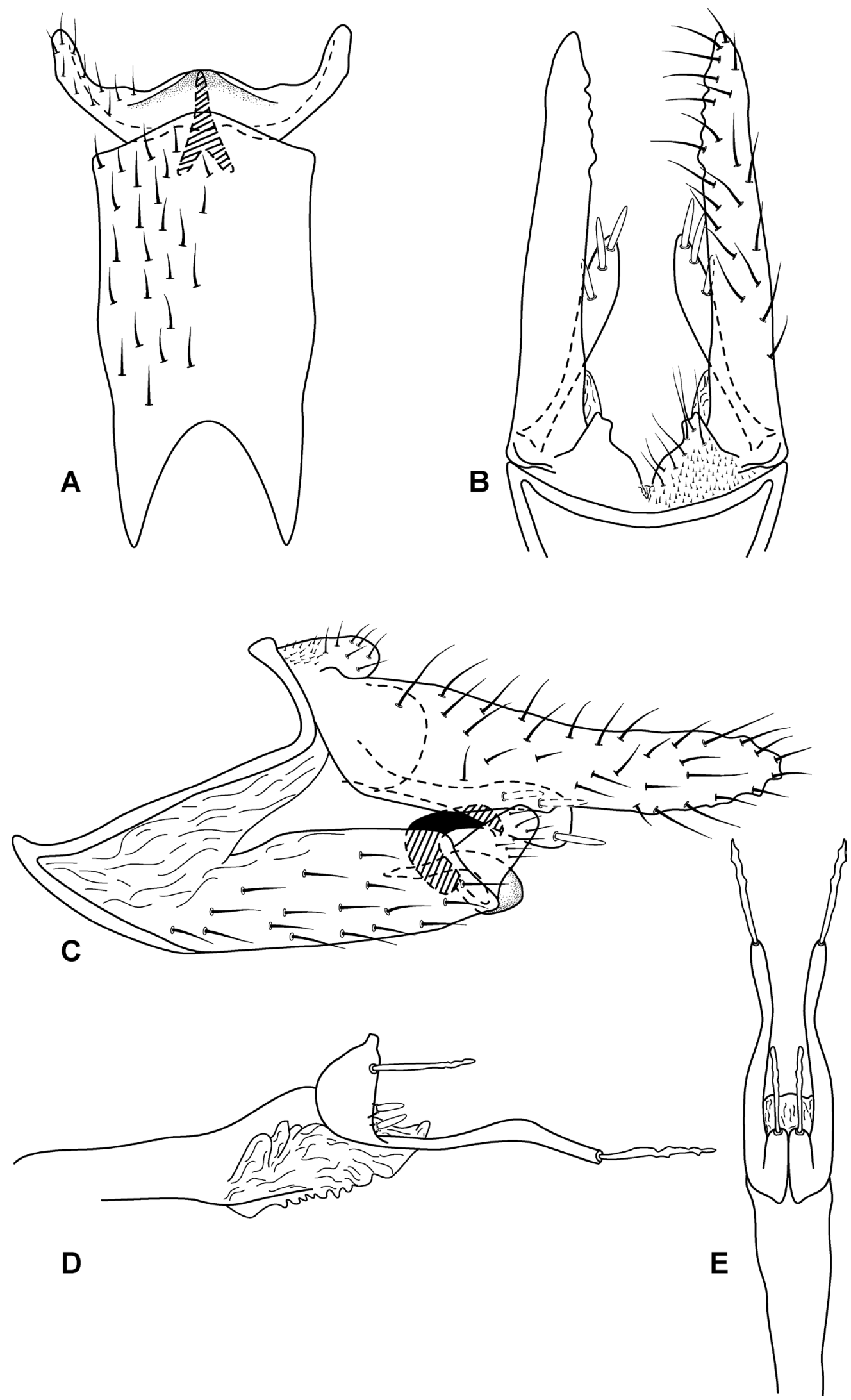

Fig. 10. Austrotinodes lenti sp. nov., male genitalia. A. Ventral view. B. Dorsal view. C. Left lateral view. D. Phallic apparatus, left lateral view. E. Phallic apparatus, dorsal view. 
WINGS. Forewing with R1 forked apically, forks II-V present; hind wing with forks II, III and V, discoidal cell absent.

Male genitalia. Segment IX deeply divided, sternum elongate; in lateral view, margins parallel-sided from distal half, ventral margin curved basally; in ventral view, about 2 times as long as wide, lateral margins almost straight, parallel-sided, apical margin convex. Phallic guide darkly sclerotized, not highly elevated; in lateral view, curved at almost right-angle, base moderately broad, apex rounded, reaching middle of inferior appendage. Inferior appendages fused mesally, attached apicomesally on sternum IX; in lateral view, stout, ovate, apex rounded; in ventral view, lateral lobes extremely elongate, directed posterolaterally, posterior margin highly concave, slightly crenulated, with mesal emargination. Tergum $\mathrm{X}$ divided into pair of semimembranous subtriangular lobes, lobes bulbous, bearing slender dorsal setae along inner margin; in lateral view, elongate. Preanal appendages very long, surface setose, margin crenulated, parallel-sided, apex rounded. Intermediate appendages slightly longer than half-length of preanal appendage; in lateral view, club-like, with 3 spine-like setae at apical third, 2 of them positioned subapically. Phallus with sclerotized phallobase and membranous apicoventral region; lateral process elongate, widest at base, ladle-like as viewed laterally; dorsal branch short, with 3 spines at posterior margin, the dorsal one 3 times longer than the ventral ones; ventral branch slender, with an elongate apical spine; without basomesal process.

\section{Distribution}

Brazil (MG).

$$
\begin{aligned}
& \text { Austrotinodes santosdumonti sp. nov. } \\
& \text { urn:1sid:zoobank.org:act:7B6268ED-6287-4398-BBB8-4291F9268791 }
\end{aligned}
$$
Figs 11,14

\section{Diagnosis}

This new species resembles A. abrachium Thomson \& Holzenthal, 2010 by the shape of the elongate segment IX, and by the elongate preanal appendages. It can be distinguished from all other species of the genus by the structure of the intermediate appendages, which are dorsally enlarged near their apex, and bear a single apical spine-like setae on this projection. Additionally, the unusual structure of the phallus, with the dorsal branch of the lateral process short, pointed apically, and the ventral branch widest basomedially, with 2 spines at its apex.

\section{Etymology}

The species is dedicated to the Brazilian inventor Alberto Santos Dumont, who was born at Palmira (now Santos Dumont) in Minas Gerais state in 1873 and died in 1932. Santos Dumont is considered the "Father of Flight" and "Aviation Pioneer" because he invented the first true airplane called 14 BIS, which flew a distance of 220 meters at a height of 6 meters and at a speed of about $40 \mathrm{~km} / \mathrm{h}$, in Paris on November $12^{\text {th }}, 1906$.

\section{Material examined}

\section{Holotype}

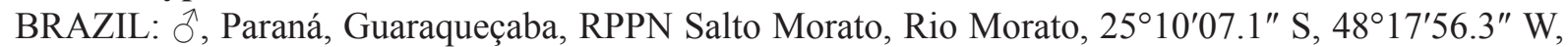
36 m, 25 Jan. 2011, L.L. Dumas and A.P.M. Santos leg. (DZRJ).

\section{Paratypes}

BRAZIL: Paraná: $4 \hat{\jmath} \widehat{\partial}$, same data as holotype (DZRJ); $2 \hat{\jmath} \widehat{\partial}, 3$ $q$ q , Guaraqueçaba, RPPN Salto Morato,

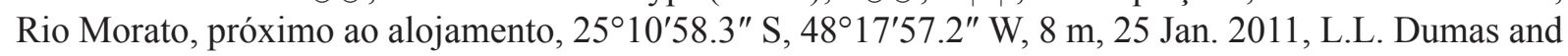




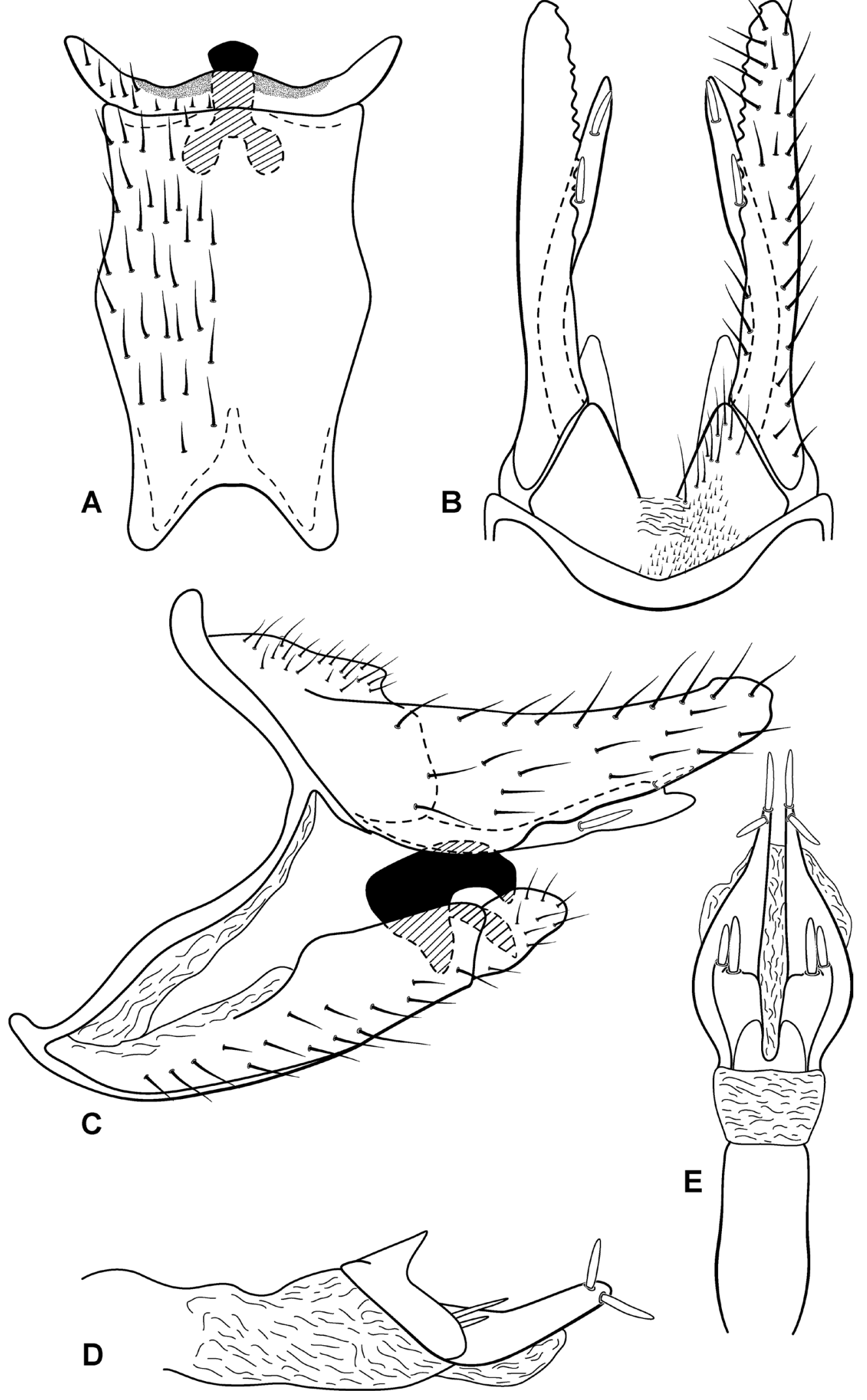

Fig. 11. Austrotinodes santosdumonti sp. nov., male genitalia. A. Ventral view. B. Dorsal view. C. Left lateral view. D. Phallic apparatus, left lateral view. E. Phallic apparatus, dorsal view. 
A.P.M. Santos leg. (DZRJ); $4 \hat{\jmath} \widehat{\partial}$, Guaraqueçaba, Ribeirão do Engenho, $25^{\circ} 10^{\prime} 31.0^{\prime \prime} \mathrm{S}, 48^{\circ} 22^{\prime} 16.2^{\prime \prime} \mathrm{W}$, 25 m, 25 Jan. 2011, L.L. Dumas and J.L. Nessimian leg. (DZRJ); 1 ô, 1 + , Morretes, Serra da Graciosa,

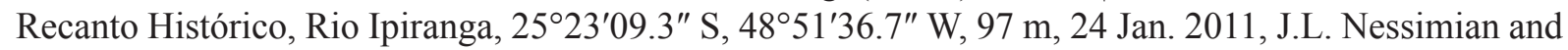
R.B. Braga leg. (DZRJ). — Rio de Janeiro: $1{ }^{\lambda}, 1$ q, Macaé, Duas Barras, $22^{\circ} 15^{\prime} 21.9^{\prime \prime} \mathrm{S}, 42^{\circ} 03^{\prime} 45.4^{\prime \prime} \mathrm{W}$, 198 m, 22 Mar. 2009, G.A. Jardim and J.L. Nessimian leg. (DZRJ); 1 ô, 1 + , Macaé, estrada Frade-Sana,

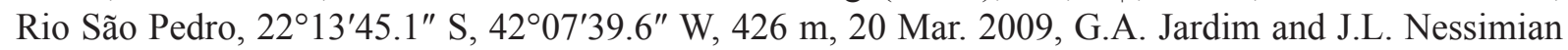

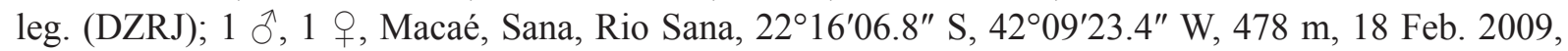
J.L. Nessimian, G.A. Jardim, L.L. Dumas, B.H.L. Sampaio and I.C. Gonçalves leg. (DZRJ); 1 ${ }^{\widehat{ }}$, Macaé, Curubixais de Cima, afluente de $2^{\mathrm{a}}$ ordem do Rio Curubixias, 22 $2^{\circ} 11^{\prime} 38.4^{\prime \prime} \mathrm{S}, 42^{\circ} 04^{\prime} 46.1^{\prime \prime} \mathrm{W}, 217 \mathrm{~m}, 21$ Mar. 2009, G.A. Jardim and J.L. Nessimian leg. (DZRJ); 1 đ̄, Macaé, Sana, afluente de $2^{\mathrm{a}}$ ordem do Rio Sana, 22 ${ }^{\circ} 19^{\prime} 17.7^{\prime \prime}$ S, 42 $2^{\circ} 10^{\prime} 58.0^{\prime \prime}$ W, 313 m, 16 Feb. 2009, G.A. Jardim and J.L. Nessimian leg. (DZRJ);

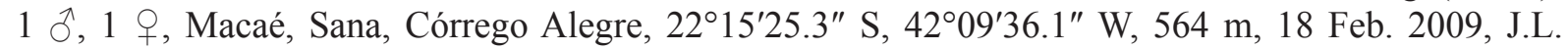
Nessimian, G.A. Jardim, L.L. Dumas, B.H.L. Sampaio and I.C. Gonçalves leg. (DZRJ); 1 ô, 1 + , Nova

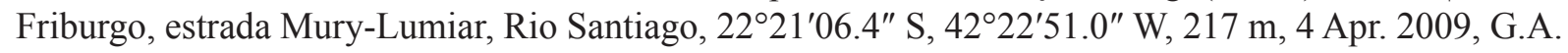
Jardim and J.L. Nessimian leg. (DZRJ); $2 \hat{\jmath} \widehat{\jmath}$, Nova Friburgo, Ramalhete, Rio Bonito em $5^{\mathrm{a}}$ ordem, $22^{\circ} 24^{\prime} 38.5^{\prime \prime}$ S, 42 20'40.7" W, 656 m, 6 Mar. 2009, G.A. Jardim and J.L. Nessimian leg. (DZRJ); 3 §ð’,

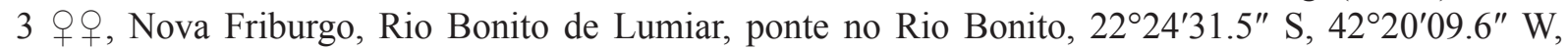
6658 m, Mar. 2009, G.A. Jardim and J.L. Nessimian leg. (DZRJ); $1 \partial^{\lambda}$, Paraty, afluente de $1^{\mathrm{a}}$ ordem do

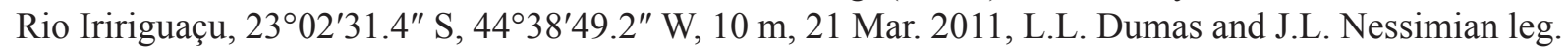

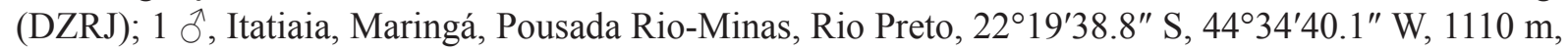
23 Nov. 2009, J.L. Nessimian leg. (DZRJ). - São Paulo: 1 ô, Ubatuba, PE da Serra do Mar, Núcleo

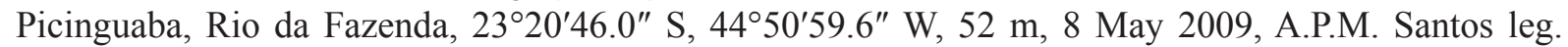
(DZRJ); 1 స, 2 우, Ubatuba, PE da Serra do Mar, Núcleo Picinguaba, Rio da Canoa, 2320'53.4" S, 4450'59.0" W, 93 m, 3 Nov. 2006, L.L. Dumas leg. (DZRJ).

\section{Description}

AduLt. Length of forewing 4.10-5.30 mm $(\mathrm{n}=10)$. In alcohol, general color yellowish brown, with golden brown sclerites; antennae stramineous, dorsum of head golden brown, with pale yellow and dark brown setae; thorax and legs yellow, legs segments with brown setae; wings pale yellow, forewing with fine pale yellow setae dorsally.

WINGS. Forewing with R1 forked apically, forks II-V present; hind wing with forks II, III and V, discoidal cell absent.

Male Genitalia. Segment IX deeply divided, sternum elongate; in lateral view, enlarging at midlength, ventral margin curved basally; in ventral view, about 2 times as long as wide, enlarged medially, apical margin slightly concave. Phallic guide darkly sclerotized, elevated over inferior appendages; in lateral view, strongly arched, base broad, apex rounded, reaching middle of inferior appendage. Inferior appendages fused mesally, attached apicomesally on sternum IX; in lateral view, ovate, apex rounded; in ventral view, lateral lobes very elongate, strongly narrowed, directed posterolaterally, posterior margin concave, not crenulated. Tergum X divided into pair of semimembranous subtriangular lobes, lobes bulbous, bearing slender setae along inner margin; in lateral view, rectangular. Preanal appendages long, surface setose, margin crenulated, widest basally, narrowing apically, apex rounded. Intermediate appendages long, approximately $3 / 4$ length of preanal appendage; in lateral view, rod-like, slightly curved dorsad, with 2 stout setae, 1 at apical third and 1 subapically positioned on a dorsal elevation. Phallus with sclerotized phallobase and membranous apicoventral region; lateral process moderately elongate, bifid; dorsal branch short, robust, pointed dorsoapically, posterior margin with 2 spines on ventral half; ventral branch long, widest medially, narrowing to apex as viewed dorsally, with 2 apical spines; without basomesal process. 


\title{
Distribution
}

Brazil (PR, RJ, SP).

\author{
Austrotinodes vanzolinii sp. nov. \\ urn:1sid:zoobank.org:act:146B8D08-E6F3-4FD4-A70D-DEE41DD5CCAB
}

Figs 12,14

\section{Diagnosis}

This species resembles A. taquaralis and correlated species by the overall shape of intermediate appendages, but can be easily distinguished by the presence of a row of 4 mesoventrally stout spine-like setae, absent in the previously described species. Additionally, the phallic apparatus is distinctive among the new species and the species of the A. taquaralis complex, with 2 long spines positioned midlaterally at the base of the lateral process and not near apex of dorsal branch as in the other species.

\section{Etymology}

The species is dedicated to the Brazilian herpetologist and music composer Paulo Emilio Vanzolini, who was born in São Paulo in São Paulo state in 1924 and died in 2013. Paulo Vanzolini was one of the scientists who contributed to the development of the "Refugia Theory" of tropical diversification. He is also considered as one of the greatest samba composers of the country, with more than 70 musical compositions, including the famous "Ronda", "Volta Por Cima" and "Boca da Noite".

\section{Material examined}

\section{Holotype}

BRAZIL: Ō, São Paulo, São José do Barreiro, PN da Serra da Bocaina, Ribeirão da Prata, 22 46'48.9" S, 44³6'40.4" W, 1200 m, 19 Dec. 2010, L.L. Dumas and J.L. Nessimian leg. (DZRJ).

\section{Description}

Adult. Length of forewing $5.00 \mathrm{~mm}(\mathrm{n}=1)$. In alcohol, general color yellowish brown, with golden brown sclerites; antennae yellow, dorsum of head golden brown, with pale yellow and dark brown setae; thorax and legs yellow, legs segments with brown setae; wings pale yellow, forewing with fine pale yellow setae dorsally.

WINGS. Forewing with R1 forked apically, forks II-V present; hind wing with forks II, III and V, discoidal cell absent.

Male genitalia. Segment IX deeply divided, sternum elongate; in lateral view, margins parallel-sided, ventral margin slightly convex; in ventral view, about 1.5 times as long as wide, enlarged near apex, apical margin almost straight. Phallic guide darkly sclerotized, not highly elevated; in lateral view, strongly arched, base broad, apex subacute, not reaching the inferior appendage. Inferior appendages fused mesally, attached apicomesally on sternum IX; in lateral view, elongate, subovate, apex rounded; in ventral view, lateral lobes elongate, directed posterolaterally, posterior margin concave, slightly crenulated, with mesal emargination. Tergum X divided into pair of semimembranous subtriangular lobes, lobes bulbous, bearing slender dorsal setae; in lateral view, subrectangular, elongate. Preanal appendages long, surface setose, margin crenulated, parallel-sided, apex rounded. Intermediate appendages long, asymmetric in holotype, approximately $3 / 4$ length of preanal appendage; in lateral view, wide at base, tapering apically, slightly curved dorsad, with a row of 4 midventral spine-like setae, left appendage with small dorsal projection at apical third bearing an apical spine-like seta and a single subapical spine-like seta, right appendage without dorsal projection and with 2 subapical spine-like setae, one more than 2 times longer than other. Phallus with sclerotized phallobase and membranous 

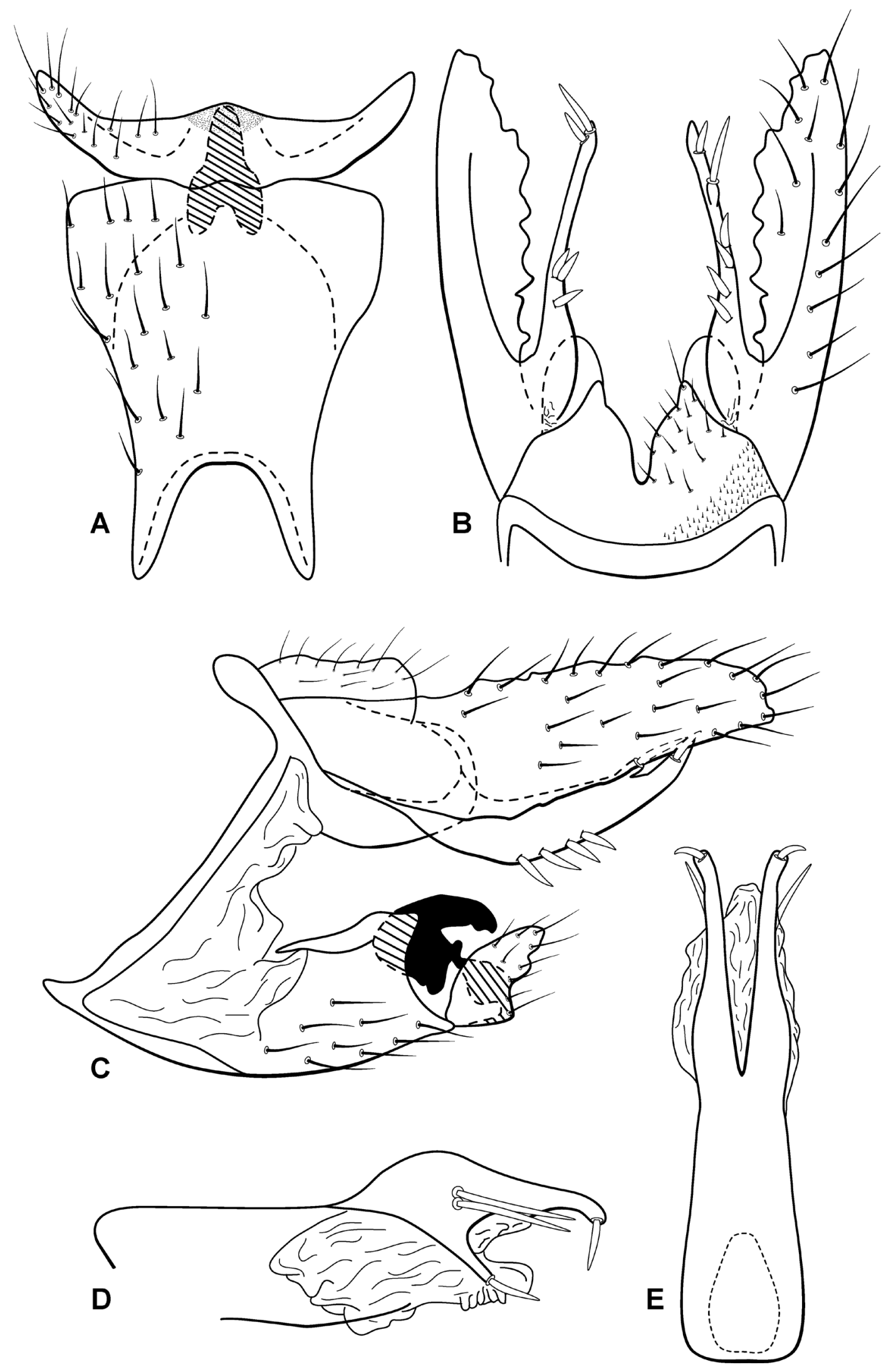

Fig. 12. Austrotinodes vanzolinii sp. nov., male genitalia. A. Ventral view. B. Dorsal view. C. Left lateral view. D. Phallic apparatus, left lateral view. E. Phallic apparatus, dorsal view. 
apical region; lateral process elongate, bifid; dorsal branch long, wide, with 2 long spines basolaterally and 1 apical stout spine at apex; ventral branch narrow, with 1 apical spine; without basomesal process.

\title{
Distribution
}

Brazil (SP).

\author{
Austrotinodes vitalbrazili sp. nov. \\ urn:1sid:zoobank.org:act:5DA68075-1D46-458C-BFF2-16AF3993EF6A
}

Figs 13, 14

\section{Diagnosis}

Austrotinodes vitalbrazili sp. nov. is closely related to A. paraguayensis Flint, 1983, resembling that species in the shape of intermediate appendages, the elongate phallic guide and the phallic apparatus. Although there is a general similarity in the intermediate appendages, the apex, which is truncate in both species, bears a short process in A. paraguayensis, whereas in the new species the apex is acute, without a process. The phallus of both species has a bifid lateral process, with dorsal and ventral branches well developed, and bears a basomesal process. However, in $A$. vitalbrazili sp. nov. the elongate ventral branch has a pair of dorsal spines at midlength, absent in A. paraguayensis. Additionally, in the new species the anterior margin of inferior appendages is slightly concave in ventral view, while in A. paraguayensis it is strongly convex.

\section{Etymology}

The species is dedicated to the Brazilian biomedical scientist and immunologist Vital Brazil Mineiro da Campanha, who was born in Campanha in Minas Gerais state in 1865 and died in 1950. Vital Brazil was renowned for the discovery of the polyvalent anti-ophidic serum, used to treat bites of species belonging to several genera of venomous snakes. He also developed anti-scorpion and anti-spider serums, and was the founder of the "Butantan Institute," which was the first in the world dedicated exclusively to basic and applied toxicology.

\section{Material examined}

\section{Holotype}

BRAZIL: ${ }^{\top}$, Minas Gerais, Jaboticatubas, PN da Serra do Cipó, Córrego das Pedras, 19²2'16.7" S, 4336'02.8” W, 766 m, 9-13 Nov. 2011, A.P.M. Santos, D.M. Takiya and M. Monné leg. (DZRJ).

\section{Paratypes}

BRAZIL: Minas Gerais: 1 त, same locality as holotype, 2 Mar. 2006, A.L.H. Oliveira leg. (DZRJ);

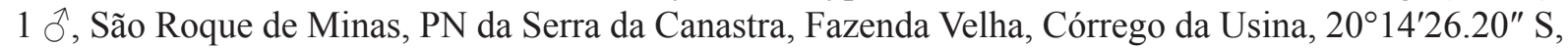
46³8'19.0" W, 1000 m, 2 Apr. 2014, J.L. Nessimian, A.L.H. Oliveira, L.L. Dumas and S.P. Gomes leg. (DZRJ); 1 $\widehat{\delta}$, São Roque de Minas, PN da Serra da Canastra, Fazenda Velha, afluente do Ribeirão das Posses (Córrego dos Pombos), 20¹4'56.60" S, 46³8'04,90" W, 997 m, 2 Apr. 2014, J.L. Nessimian, A.L.H. Oliveira, L.L. Dumas and S.P. Gomes leg. (DZRJ); 1 ô, São Roque de Minas, PN da Serra da Canastra, Cachoeira Capão Forro (confluência dos rios Peixe e Rolador), 20 $15^{\prime} 10.0^{\prime \prime}$ S, 46 $24^{\prime} 24.0^{\prime \prime} \mathrm{W}$, 936 m, 31 Mar. 2014, J.L. Nessimian, A.L.H. Oliveira, L.L. Dumas and S.P. Gomes leg. (DZRJ); 1 ठ, São Roque de Minas, PN da Serra da Canastra, parte alta da Cachoeira do Rolinho, Rib. da Mata, $20^{\circ} 10^{\prime} 29.9^{\prime \prime} \mathrm{S}, 46^{\circ} 33^{\prime} 36.1^{\prime \prime} \mathrm{W}, 1193$ m, 16 Nov. 2014, J.L. Nessimian, A.L.H. Oliveira, I.C. Rocha and P.M. Souto leg. (DZRJ); 1 đ̃, São Roque de Minas, PN da Serra da Canastra, 31 Mar.-4 Apr. 2014, J.L. Nessimian, A.L.H. Oliveira, L.L. Dumas and S.P. Gomes leg. (DZRJ). 

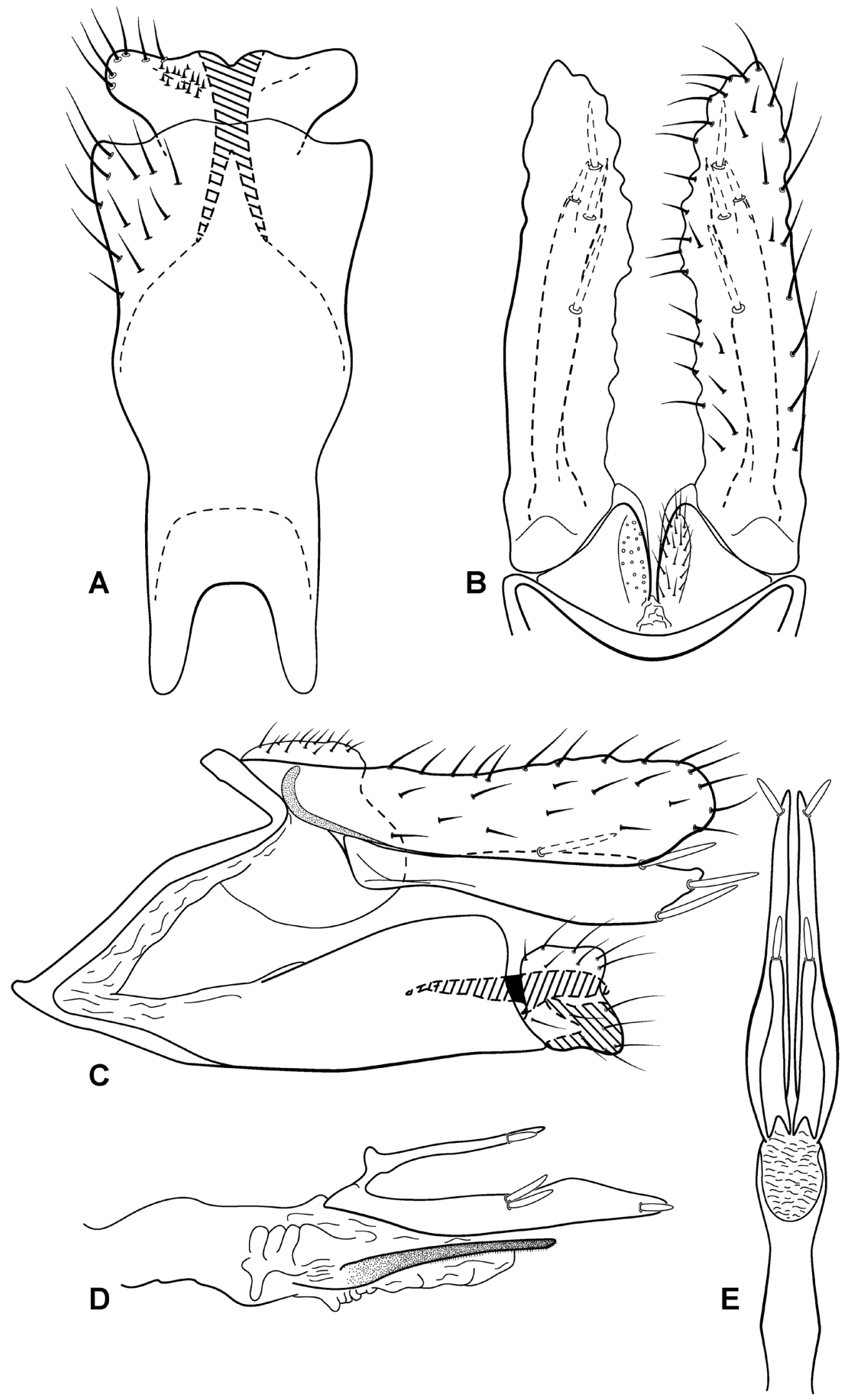

Fig. 13. Austrotinodes vitalbrazili sp. nov., male genitalia. A. Ventral view. B. Dorsal view. C. Left lateral view. D. Phallic apparatus, left lateral view. E. Phallic apparatus, dorsal view. 


\section{Description}

ADULT. Length of forewing 4.00-4.75 mm ( $\mathrm{n}=6)$. In alcohol, general color golden brown, with golden brown sclerites; antennae stramineous, dorsum of head golden brown, with pale yellow and dark brown setae; thorax golden brown dorsally, light yellow ventrally; legs yellow, legs segments with brown setae; wings pale brown, forewing with fine pale brown setae dorsally.

WINGS. Forewing with R1 forked apically, forks II-V present; hind wing with forks II, III and V, discoidal cell absent.

MaLE GENITALIA. Segment IX deeply divided, sternum extremely elongate; in lateral view, narrow at base, enlarging apically, ventral margin slightly convex; in ventral view, more than 2 times as long as wide, enlarging apically, apical margin slightly convex. Phallic guide darkly sclerotized, narrow, elongate, not elevated; in lateral view, straight, base acute, apex subacute, reaching tip of inferior appendage. Inferior appendages fused mesally, attached apicomesally on sternum IX; in lateral view, stout, quadrate, apex truncated; in ventral view, less wide than tergum IX, lateral lobes short, directed posterolaterally, posterior margin slightly convex, not crenulated, with shallow mesal emargination. Tergum X divided into pair of semimembranous ovate lobes, lobes bulbous, bearing slender dorsal setae along inner margin; in lateral view, ovate, elongate. Preanal appendages long, surface setose, margin crenulated, parallel-sided, apex rounded. Intermediate appendages long, approximately $3 / 4$ length of preanal appendage; in lateral view, parallel-sided, enlarging apically, with 1 middorsal, 2 subapical (1 dorsal and 1 lateroventral) and 1 apical spine-like setae, apex acute. Phallus with sclerotized phallobase and membranous apical region;

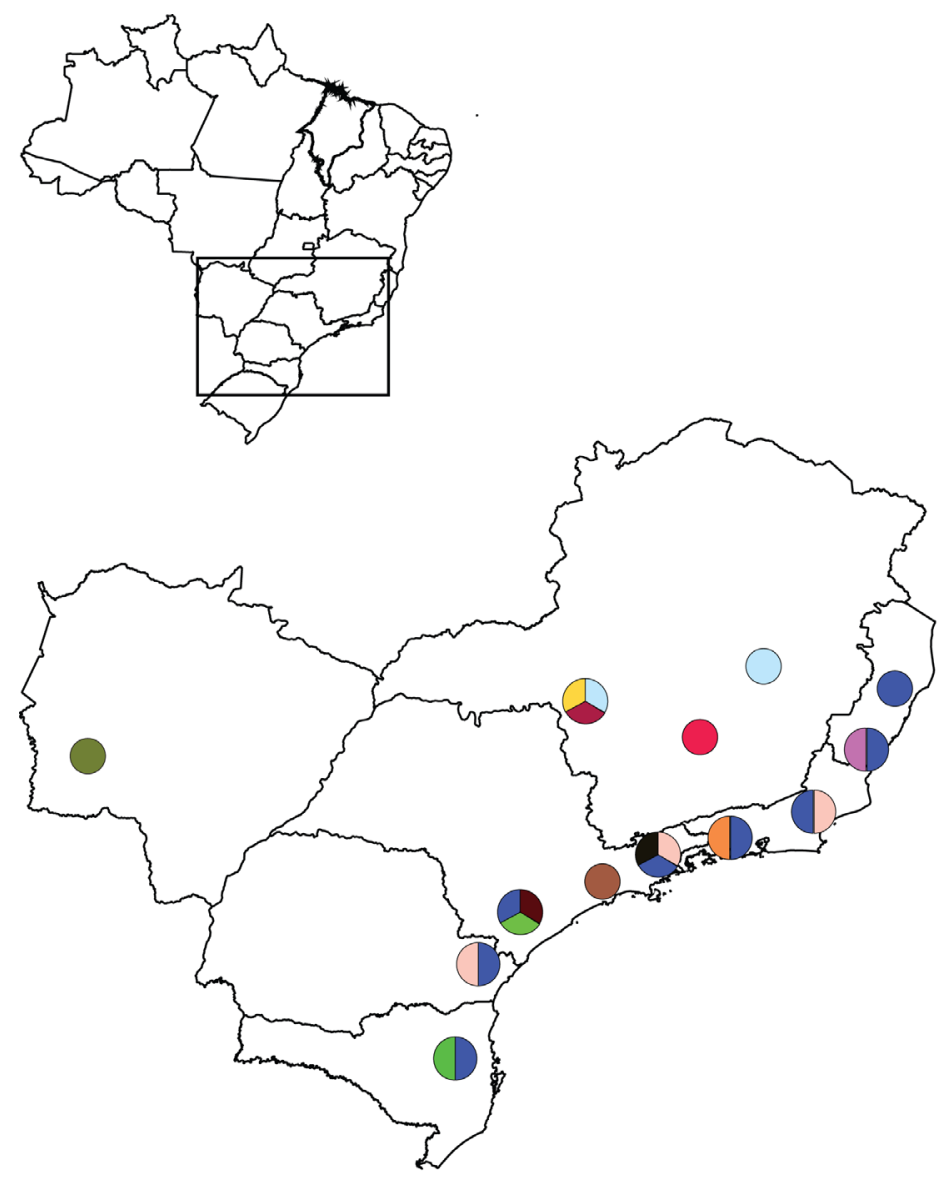

\section{Legends}

Austrotinodes absaberi sp. nov.

Austrotinodes adolfolutzi sp. nov.

Austrotinodes berthalutzae sp. nov.

Austrotinodes chagasi sp. nov.

Austrotinodes costalimai sp. nov.

Austrotinodes cruzi sp. nov.

Austrotinodes donagrazielae sp. nov.

Austrotinodes gusmaoi sp. nov.

Austrotinodes lattesi sp. nov.

Austrotinodes lenti sp. nov.

Austrotinodes santosdumonti sp. nov.

Austrotinodes vanzolinii sp. nov.

Austrotinodes vitalbrazili sp. nov.

Fig. 14. Distribution map of the new species of Austrotinodes. 
lateral process very elongate, bifid; dorsal branch short, narrow, rod-like, with 1 long apical spine; ventral branch long, about 2 times longer than dorsal branch, wide, with 2 middorsal and 1 subapical spines, apex rounded; basomesal process elongate, narrow, darkly sclerotized.

\section{Distribution}

Brazil (MG).

Austrotinodes amazonensis Flint \& Denning, 1989

Fig. 15

Austrotinodes amazonensis Flint \& Denning, 1989: 119 [Type locality: Brazil, Amazonas state, Hwy. Am. 010, km 246, 20 km W Itacoatiara; holotype depository: MZSP; male].

Austrotinodes amazonensis - Flint et al. 1999: 19 [catalog]. — Paprocki et al. 2004: 5 [checklist]. Paprocki \& França 2014: 7 [checklist].

\section{Material examined}

BRAZIL: 1 đ̃; Minas Gerais, São João Batista do Glória, PN da Serra da Canastra, Ribeirão Grande (pousada Mata do Engenho), 20³0'53.9" S, 46³0'49.2" W, 24 Mar. 2015, 698 m, J.L. Nessimian, L.L. Dumas, I.C. Rocha, A.L.H. Oliveira and S.P. Gomes leg. (DZRJ).

\section{Remarks}

Austrotinodes amazonensis can be easily distinguished from other species of the genus by the deeply divided apex of the elongate phallic guide, intermediate appendages with a short ventral projection in the basal half, bearing an apical spine-like seta, and the unusual lateral process of the phallus, with the ventral branch forked. Other important characteristics of this species are the elongate segment IX with a strongly convex posterior margin and the inferior appendages with a wide V-shaped incision (best observed in ventral view). Additionally, the phallic apparatus has a dark basomesal process. For comparative purposes, A. amazonensis is reillustrated here in order to better observe the male genitalic structures, especially the phallic apparatus.

Austrotinodes amazonensis is reported here for the first time from Minas Gerais state, southeastern Brazil, based on a specimen collected in the Serra da Canastra mountain range in the Atlantic ForestCerrado ecotone site. This is the first reported occurrence of this species outside of its Amazon core distribution.

\section{Austrotinodes longispinum Thomson \& Holzenthal, 2010}

Austrotinodes longispinum Thomson \& Holzenthal, 2010: 45, fig. 5a-f. [Type locality: Brazil, São Paulo, Cachoeira do Paredão, Lajeado, Serra da Bocaina, 22 ${ }^{\circ} 43.533^{\prime}$ S, $44^{\circ} 37.274^{\prime} \mathrm{W}, 1550 \mathrm{~m}$; holotype depository: MZSP; male].

Austrotinodes longispinum - Paprocki \& França 2014: 7 [checklist].

\section{Material examined}

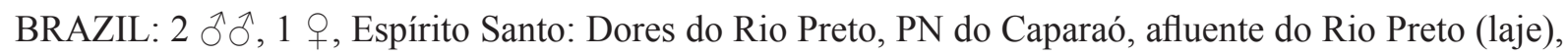
20²9'26.2" S, 4149'17.1" W, 11-15 Jan. 2015, 1507 m, J.L. Nessimian and A.L.H. Oliveira leg. (DZRJ). 


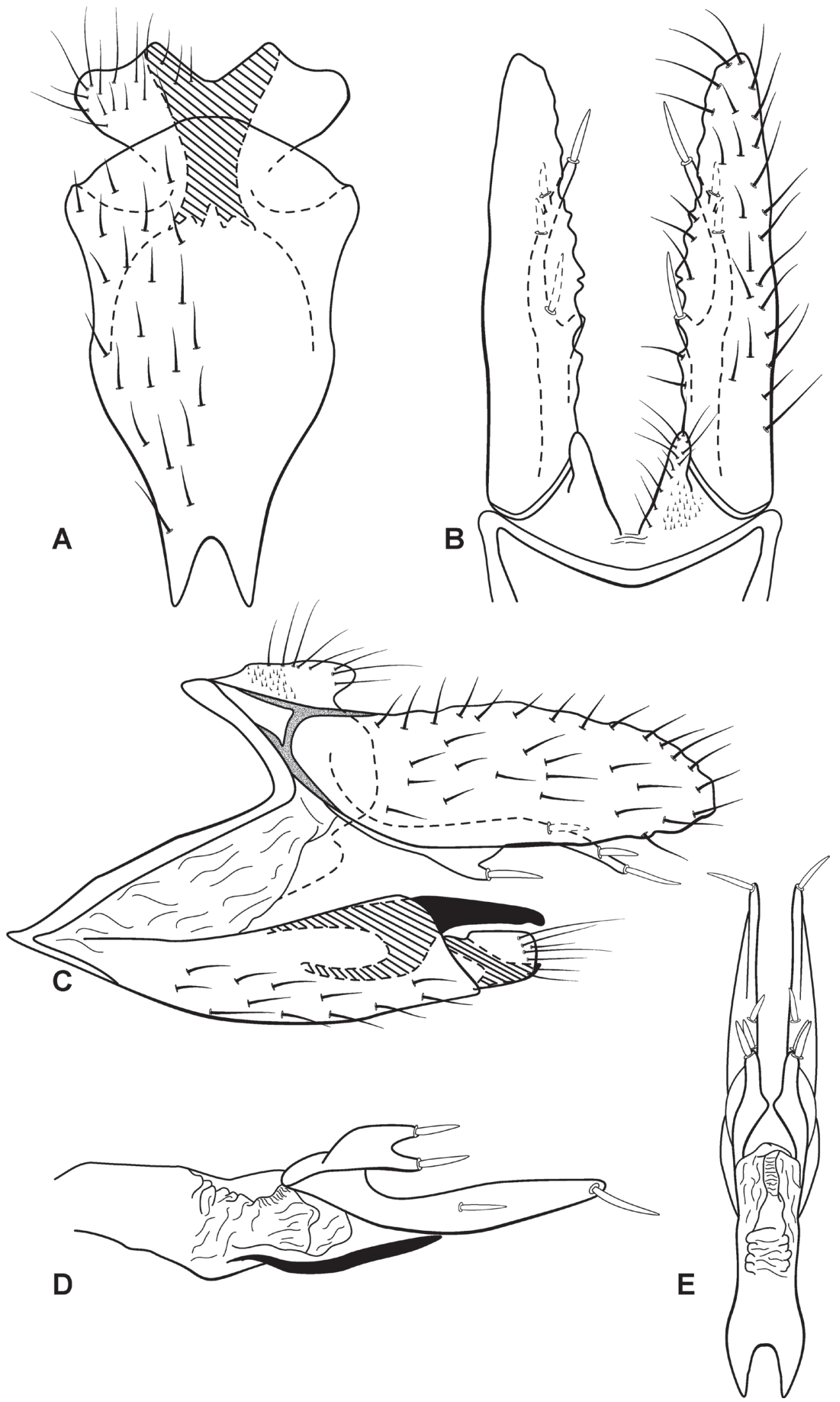

Fig. 15. Austrotinodes amazonensis Flint \& Denning, 1989, male genitalia. A. Ventral view. B. Dorsal view. C. Left lateral view. D. Phallic apparatus, left lateral view. E. Phallic apparatus, dorsal view. 


\section{Remarks}

Despite the resemblance with $A$. prolixus Flint \& Denning, 1989, especially regarding the intermediate appendages, this species can be recognized by the unique setation of the lateral process of the phallus, which has an extremely elongate mesolateral spine and a small apical one.

A. longispinum was originally reported from high altitude areas of the Atlantic Forest domain in the Serra do Mar mountain range (São Paulo and Rio de Janeiro states). We collected this species at a similar site, but in the Serra da Mantiqueira mountain range, in Espirito Santo state, the first record of A. longispinum for this state.

Austrotinodes paraguayensis Flint, 1983

Fig. 16

Austrotinodes paraguayensis Flint, 1983: 119 [Type locality: Paraguay, Dpto. Paraguai, Colonia Piraretá; holotype depository: NMNH; male].

Austrotinodes paraguayensis - Flint \& Denning 1989: 117 [distribution, correction of the original figure]. - Flint et al. 1999: 20 [catalog]. — Paprocki et al. 2004: 5 [checklist]. — Paprocki \& França 2014: 7 [checklist]. — Takiya et al. 2016: 157 [distribution].

\section{Material examined}

BRAZIL: Minas Gerais: 1 , São Roque de Minas, PN da Serra da Canastra, Rio São Francisco, parte alta da Casca D'Anta, 2014'37.3" S, 46³8'42.7" W, 15 Nov. 2014, 956 m, J.L. Nessimian, A.L.H. Oliveira, I.C. Rocha and P.M. Souto leg. (DZRJ); 1 ${ }^{\lambda}$, Delfinópolis, PN da Serra da Canastra, Ribeirão Dona Candinha (Pousada Acqualume), 20¹9'56.5" S, 4649'07.9" W, 26 Mar. 2015, 745 m, J.L. Nessimian, L.L. Dumas, I.C. Rocha, A.L.H. Oliveira and S.P. Gomes leg. (DZRJ); 2 $\widehat{\jmath}$, Delfinópolis, PN da Serra da Canastra, Ribeirão Laurinha (Pousada Águas de Santo Antônio), 20²6'28.5" S, 46² ${ }^{\prime} 10.9^{\prime \prime}$ W, 25 Mar. 2015, 683 m, J.L. Nessimian, L.L. Dumas, I.C. Rocha, A.L.H. Oliveira and S.P. Gomes leg. (DZRJ); 1 స̃, Delfinópolis, PN da Serra da Canastra, Ribeirão da Forquilha, 20¹8'55.6" S, 46²9'59.0" W, 26 Mar. 2015, 720 m, J.L. Nessimian, L.L. Dumas, I.C. Rocha, A.L.H. Oliveira and S.P.

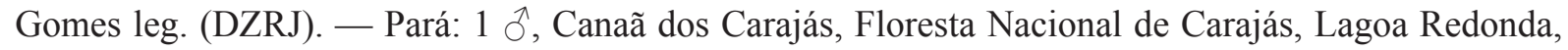
06²1'20.7" S, 50²3'26.7" W, 14 Nov. 2006, 705 m, N Ferreira Jr leg. (DZRJ).

\section{Remarks}

According to Flint (1983), this species is most closely related to a Central American group of species. However, as discussed in the diagnosis for $A$. vitalbrazili sp. nov., the closest relationship of these two species is with each other, distinguished by structures of the intermediate and inferior appendages. Austrotinodes paraguayensis can be diagnosed by the large truncate apex of the intermediate appendages, with a short apical process and 4 spine-like setae; inferior appendages with the posterior margin convex, bearing a short U-shaped incision; and a phallic apparatus with a dark basomesal process, a lateral process bearing a robust, upturned dorsal branch, with a large, rugose apical spine, and an elongate ventral branch, with a slender, curved, rugose apical spine. The phallic guide is elongate, but without an almost truncate apex, as described by Flint \& Denning (1989) for specimens collected in Serra do Cipó, Minas Gerais state. Rather, it has a finger-like apical projection. As in A. amazonensis, the genitalic structure of this species is also reillustrated to facilitate comparison with others species of the genus.

We report here records of $A$. paraguayensis collected in the Serra da Canastra, a mountainous area in Minas Gerais state. Additionally, this species was also collected and is reported for the first time from Pará state, north Brazil, based on a single specimen collected in the Floresta Nacional de Carajás, an outstanding conservation area with typical Amazon tropical forest. The forested areas are interrupted 


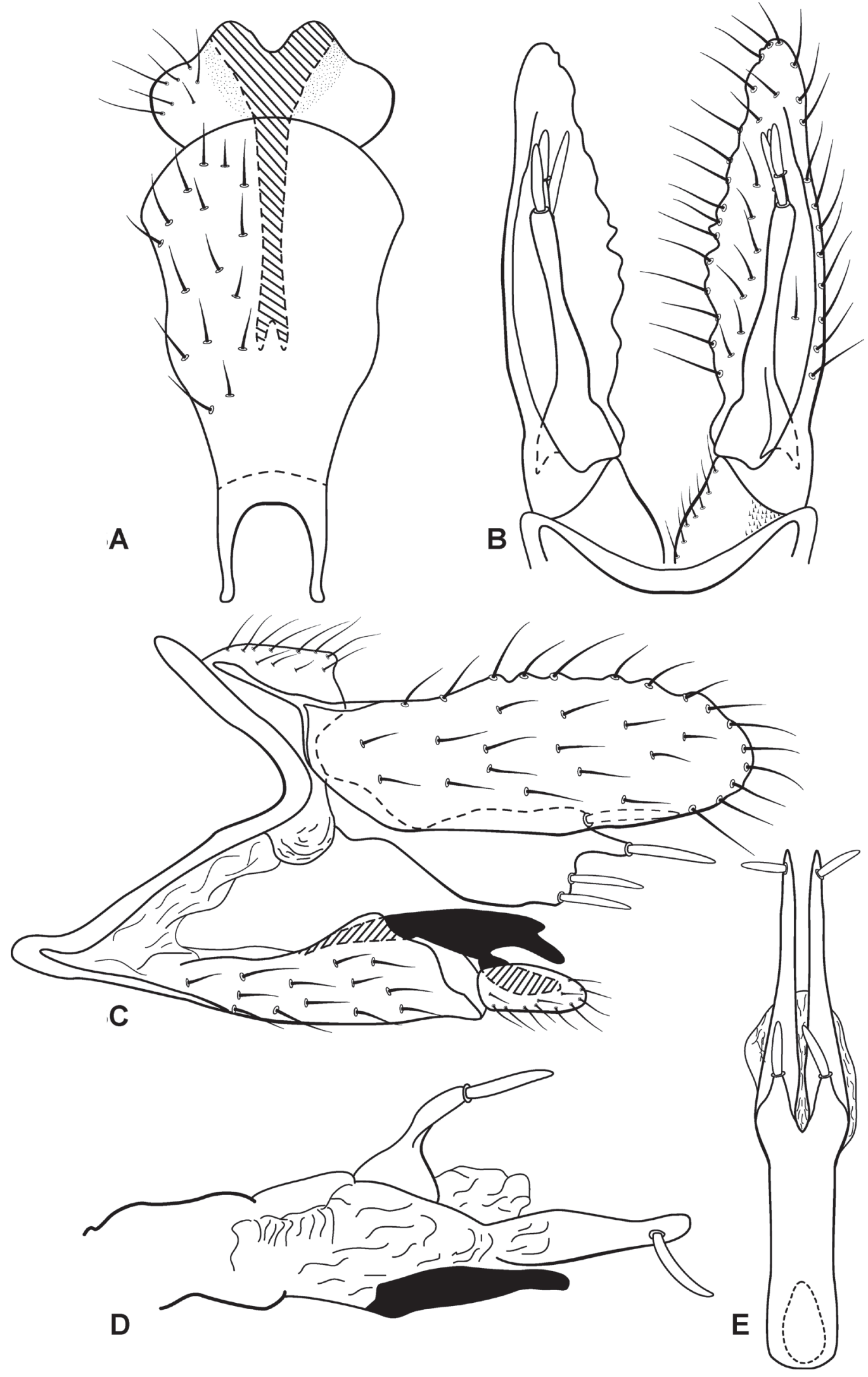

Fig. 16. Austrotinodes paraguayensis Flint, 1983, male genitalia. A. Ventral view. B. Dorsal view. C. Left lateral view. D. Phallic apparatus, left lateral view. E. Phallic apparatus, dorsal view. 
by natural clearings, where there are rocky outcrops of iron, generically called "Canga," covered with savannah vegetation.

Austrotinodes taquaralis Thomson \& Holzenthal, 2010

Austrotinodes taquaralis Thomson \& Holzenthal, 2010: 47, fig. 6a-f [Type locality: Brazil, Rio de

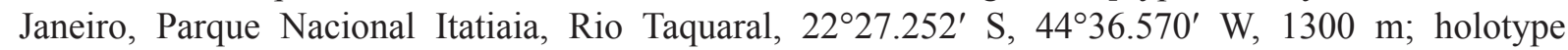
depository: MZSP; male].

Austrotinodes taquaralis - Paprocki \& França 2014: 7 [checklist].

\section{Material examined}

BRAZIL: 1 ภ, Espírito Santo, Dores do Rio Preto, Pedra Menina, PN do Caparaó, Cachoeira do Aurélio, $20^{\circ} 28^{\prime} 54.5^{\prime \prime}$ S, 41 ${ }^{\circ} 50^{\prime} 12.8^{\prime \prime}$ W, 6 Jan. 2013, 1814 m, L.L. Dumas and B.H.L. Sampaio leg. (DZRJ).

\section{Remarks}

Austrotinodes taquaralis is very similar to A. donagrazielae sp. nov., A. absaberi sp. nov. and A. gusmaoi sp. nov., possibly forming a species group or complex. There are minor differences among then, as mentioned in the species diagnoses of those species. This species can be diagnosed by a set of characteristics, including intermediate appendages tapering to apex, with a single basodorsal and 3 apical spine-like setae; inferior appendages with posterior margin concave with central point; and a phallus with the lateral process bearing a short slender ventral branch with a single apical spine, and a dorsal branch with a row of 2 subapical and 1 apical unenlarged spines.

This species is commonly encountered at Atlantic Forest sites in Itatiaia, Rio de Janeiro state, and Minas Gerais. It is reported for the first time and from similar sites from Espirito Santo state.

\section{Discussion}

The first checklist of Brazilian Trichoptera (Paprocki et al. 2004) registered only six species of Austrotinodes for the country. In 2010, Thomson \& Holzenthal described four more species, bringing the total Brazilian fauna of Austrotinodes to ten species. Herein, we describe 13 more new species from Brazil, and it is possible that a very large number of new species remains unknown. These numbers (probably) reflect the fact that our knowledge of diversity of Austrotinodes, as currently reported for the Neotropical Region and especially Brazil, is still very incipient. The collection and description of the caddisfly fauna, including the ecnomids, need to be recognized as a priority in Brazil, especially for the Northeast and Midwest regions, both representing hiatuses in our knowledge of the diversity of Trichoptera.

As in virtually all groups of Neotropical caddisflies, the biology and immature stages of Austrotinodes are poorly known. To date, only immatures of A. cubanus Kumanski, 1987 and A. recta Schmid, 1964 have been described (Botosaneanu 1994; Flint 1973). This lack of knowledge of immature stages is particularly problematic, given the recognized importance of larval and pupal characters to establish a reasonable classification and phylogenetic system.

Additionally, the use of light traps, a technique extensively used for sampling caddisflies, doesn't seem to be very efficient for capturing specimens of Austrotinodes. It may account for the low number of specimens on which the descriptions of new species are commonly based. We also recommend the use of Malaise traps, placed above flowing streams with coarse substrate (where larvae are commonly found), to improve sample efforts. 


\section{Acknowledgements}

We thank the Laboratório de Entomologia (Labent, UFRJ) team and associated researchers for field assistance. This work is largely supported by the Conselho Nacional de Desenvolvimento Científico e Tecnológico (CNPq), the Fundação de Amparo à Pesquisa do Estado do Rio de Janeiro (FAPERJ) and the Coordenação de Aperfeiçoamento de Pessoal de Nível Superior (CAPES). The Instituto Brasileiro do Meio Ambiente e dos Recursos Naturais Renováveis (IBAMA), the Instituto Chico Mendes de Conservação da Biodiversidade (ICMBio), and all Conservation Units are also thanked for issuing collecting permits.

\section{References}

Angrisano E.B. 1994. Contribución al conocimiento de los Trichoptera del Uruguay. I. Familias Ecnomidae y Polycentropodidae. Revista de la Sociedad Entomologica Argentina 53: 129-139.

Botosaneanu L. 1994. A study of the larvae of caddisflies (Trichoptera) from Cuba. Tropical Zoology 7 : 451-475. https://doi.org/10.1080/03946975.1994.10539267

Bowles D.E. 1995. A new species of Austrotinodes (Trichoptera: Ecnomidae) from Texas. Journal of New York Entomological Society 103: 155-161.

Cartwright D.I. 2009. Austrotinodes Schmid, a South and Central American caddisfly genus, newly recorded in Australia, with the description of new species (Trichoptera: Ecnomidae). Zootaxa 2142: $1-19$.

Flint O.S. Jr. 1973. Studies of Neotropical caddisflies, XVI: the genus Austrotinodes (Trichoptera: Psychomiidae). Proceedings of the Biological Society of Washington 86: 127-142.

Flint O.S. Jr. 1983. Studies of Neotropical caddisflies, XXXIII: new species from austral South America (Trichoptera). Smithsonian Contributions to Zoology 377: 1-100.

Flint O.S. Jr. 1996. Studies of Neotropical caddisflies LV: Trichoptera of Trinidad and Tobago. Transactions of the American Entomological Society 122: 67-112.

Flint O.S. Jr. \& Denning D.G. 1989. Studies of Neotropical caddisflies XLI: New species and records of Austrotinodes (Trichoptera: Psychomyiidae). Pan Pacific Entomologist 65: 108-122.

Flint O.S. Jr., Holzenthal R.W. \& Harris S.C. 1999. Catalog of the Neotropical Caddisflies (Insecta: Trichoptera). Ohio Biological Survey, Columbus, Ohio.

Frost S.W. 1957. The Pennsylvania insect light trap. Journal of Economic Entomology 50: 287-292. https://doi.org/10.1093/jee/50.3.287

Gressit J.L. \& Gressit M.K. 1962. An improved Malaise Trap. Pacific Insects 4: 87-90.

Holzenthal R.W., Blahnik R.J., Prather A.L. \& Kjer K.M. 2007. Order Trichoptera Kirby, 1813 (Insecta), Caddisflies. In: Zhang Z.Q. \& Shear W.A. (eds) Linnaeus Tercentenary: Progress in Invertebrate Taxonomy: 639-698. Zootaxa 1668, Magnolia Press, Auckland, New Zealand.

Johanson K.A. \& Espeland M. 2010. Phylogeny of the Ecnomidae (Insecta: Trichoptera). Cladistics 25: 1-13. https://doi.org/10.1111/j.1096-0031.2009.00276.x

Lepneva S.G. 1970. Fauna of the USSR, Trichoptera II (1). Larvae and pupae of the Annulipalpia. Israel Program for Scientific Translation, Jerusalem.

Muñoz-Quesada F. \& Holzenthal R.W. 1993. New species and records of Costa Rican Austrotinodes (Trichoptera: Ecnomidae). Proceedings of the Entomological Society of Washington 95: 564-573. 
Paprocki H. \& França D. 2014. Brazilian Trichoptera Checklist II. Biodiversity Data Journal 2: 1-109. https://doi.org/10.3897/BDJ.2.e1557

Paprocki H., Holzenthal R.W. \& Blahnik R.J. 2004. Checklist of the Trichoptera (Insecta) of Brazil. Biota Neotropica 4: 1-22.

Schmid F. 1955. Contribution à la connaissance des Trichoptères néotropicaux. Mémoires de la Société vaudoise des Sciences Naturelles 11: 117-160.

Takiya D.M., Santos A.P.M., Pinto A.P., Henriques-Oliveira A.L., Carvalho A.L., Sampaio B.H.L., Clarkson B., Moreira F.F.F., Avelino-Capistrano F., Gonçalves I.C., Cordeiro I.R.S., Câmara J.T., Barbosa J.F., Souza W.R.M. \& Rafael J.A. 2016. Aquatic Insects from the Caatinga: checklists and diversity assessments of Ubajara (Ceará State) and Sete Cidades (Piauí State) National Parks, Northeastern Brazil. Biodiversity Data Journal 4: e8354. https://doi.org/10.3897/BDJ.4.e8354

Thomson R.E. \& Holzenthal R.W. 2010. New Neotropical species of Austrotinodes Schmid (Trichoptera: Ecnomidae). Zootaxa 2437: 38-50.

Ulmer G. 1903. Über die Metamorphose der Trichopteren. Abhandlungen und Verhandlungen des naturwissenschaftlichen Vereins in Hamburg 18: 1-154.

Ulmer G. 1907. Trichoptera. In: Wytsman P. (ed.) Genera Insectorum 60: 1-259. L. Desmet Verteneuil, Brussels.

Ulmer G. 1910. Über Bernstein Trichopteren. Zoologischer Anzeiger 36: 449-453.

Manuscript received: 30 March 2016

Manuscript accepted: 22 July 2016

Published on: 13 March 2017

Topic editor: Gavin Broad

Desk editor: Kristiaan Hoedemakers

Printed versions of all papers are also deposited in the libraries of the institutes that are members of the EJT consortium: Muséum national d'Histoire naturelle, Paris, France; Botanic Garden Meise, Belgium; Royal Museum for Central Africa, Tervuren, Belgium; Natural History Museum, London, United Kingdom; Royal Belgian Institute of Natural Sciences, Brussels, Belgium; Natural History Museum of Denmark, Copenhagen, Denmark; Naturalis Biodiversity Center, Leiden, the Netherlands. 